\title{
PRIVATE SCHOOLS IN SOUTH AFRICAN LEGAL HISTORY
}

\section{DM Pretorius*}

\section{ABSTRACT}

Following the British model, the education laws of the Colony of the Cape of Good Hope (later the Cape Province) and the Transvaal historically recognised a basic distinction between public schools and private schools. The churches played a leading role in the development of private schools, which made a significant contribution to education in South Africa, especially for black children. Private schools enjoyed a high degree of independence in the colonial and pre-apartheid period. However, these schools were brought to heel during the apartheid era, with admissions policies, curricula and language medium of instruction being brought under state control, thus impairing their independence and enforcing racial segregation.

Keywords: Education law; education history; Cape Colony; Cape Province; ZuidAfrikaansche Republiek; Transvaal; private schools; church schools; mission schools; racial segregation

\section{Introduction}

South Africa's constitutional and statutory dispensation pertaining to basic (primary and secondary) education contemplates a dichotomy between public schools and

* BA LLB (Stell) BA (Hons) LLM PGCE (SA) PhD (Witwatersrand); Partner: Bowmans, Johannesburg; quondam history master, St John's College, Johannesburg; Director, St Augustine College of South Africa. 
independent schools. ${ }^{1}$ The provenance of this bifurcation is to be found in the historical development of the South African education system, which was profoundly influenced by the British approach to education. This is a function of the fact that the education system in South Africa is, to a large extent, a product of the British colonial period: it was largely during the era of British imperial control over South Africa that the foundations of the country's education system were laid. Schools and universities established in South Africa were deliberately designed along British (especially English) lines. Aspects of the British foundations of the South African education system were dismantled during the apartheid era. However, even today the British impact on the South African education system remains discernible. One of the legacies of British colonialism is an extensive system of private schools.

Against this background, this article explores the development of primary and secondary education in South African legal history. The focus is on private schools (especially church schools) that were established in the erstwhile Cape and Transvaal territories, and on the legal framework in which they developed. Attention is given to the extent to which these schools were controlled and regulated by the state or, conversely, were able to govern their own affairs. Attention is also given to the manner in which racial segregation came to be institutionalised in South African schools.

\section{Nomenclature: Public schools and private schools}

In keeping with the situation prevailing in many anglophone countries, the South African legal system draws a fundamental distinction between public schools and independent schools. Public schools are colloquially called "state schools" or "government schools", while independent schools are known as "private schools" in common parlance. This terminological farrago is compounded by the fact that the terms "public school" and "private school" have different - indeed, opposite connotations in South Africa and the United Kingdom.

In South Africa, the term "public school" refers, at the highest level of generality, to a school that is owned, controlled and funded by the state. (This is not a definitive description. Some public schools have a degree of autonomy, charge fees and own their facilities. Conversely, some private schools are partially funded and controlled by the state.) By contrast, in the United Kingdom some independent schools have traditionally been known as "public schools". Under the Public Schools Act of 1868, only seven schools - all of them ancient boys' boarding schools - were originally

1 Constitution of the Republic of South Africa, 1996, s 29; South African Schools Act 84 of 1996, chs 3 and 5 .

2 Public Schools Act, 1868 ( 31 \& 32 Vict c 118), enacted pursuant to the proceedings of the Clarendon Commission (1861-1864). See Levi 1865: 297; Gray 1913: 31; Seldon \& Walsh 2013: 10; Shrosbree 1988: passim; Stephen 2018: 75; Turner 2015: 118; Warner 1946: 10, 30. 


\section{DM PRETORIUS}

regarded as "public schools": Charterhouse (est 1611), Eton (1440), Harrow (1571), Rugby (1567), Shrewsbury (1552), Westminster (1561) and Winchester (1382). In time, the term came to be understood more expansively to include, inter alia, Cheltenham (1841), Clifton (1862), Haileybury (1862), Lancing (1848), Malvern (1865), Marlborough (1843), Merchant Taylors' (1561), Oundle (1556), Radley (1847), Repton (1557), Rossall (1844), St Paul's (1509), Sherborne (1550), Tonbridge (1553), Uppingham (1584) and Wellington (1859). The list is not - and, by virtue of the nebulous nature of the term "public school", cannot be - exhaustive. One can add many other schools, for example Ampleforth (1802), Haberdashers' Aske's (1690), North London Collegiate School (1850), Cheltenham Ladies College (1853), Christ's Hospital (1552), Downside (1617), Dulwich (1619), Sedbergh (1525) and Stonyhurst (1593). Ultimately, the term "public school" came to encompass a large group of independent schools forming part of the Headmasters' and Headmistresses' Conference. These schools are not funded by the state, but from benefactors' endowments and fees paid by pupils (although they have some "foundation" pupils who are entitled to education that is wholly or partly gratuitous). Ownership of a public school's property is vested in its governing body, which has no pecuniary interest in the school but controls its expenditure, and has power to appoint (and remove) the headmaster, and to determine admissions policies, fees, salaries and the curriculum. How the curriculum is taught is left to the headmaster, who has control over the administration of admissions, studies and internal discipline of the school, and who appoints all staff. ${ }^{3}$

These English public schools were not set up by the state, which had little involvement in education until the 1830s. Rather, these schools were founded by pious and philanthropic bequests as charitable grammar schools intended to educate indigent children in particular localities. As the reputation of some of these schools began to spread beyond their immediate environs, they began to attract pupils from further afield. Parents who could afford to pay residential fees, rather than local parents only, sent their children to these schools, which in that sense became "public" institutions. Victorian parents tended to send sons rather than daughters to these schools, and so public schools became synonymous with boys' boarding schools. ${ }^{4}$ The process by which these local schools became "public" schools is described by WM Thackeray in his novel, Vanity Fair (1848):

His lordship extended his good-will to little Rawdon: he pointed out to the boy's parents the necessity of sending him to a public school; that he was of an age now when emulation,

3 Halsbury 2015: par 370; Harwood 2012: 5, 21; Hughes 1879a: 352ff; Hughes 1879b: 37ff; Kenway et al 2017: 17ff; McCulloch 1991: 14ff; Shrosbree 1988: 12; Turner 2015: xii et seq. Interesting historical sketches of several famous English public schools are collated in Various Authors 1893.

4 Harwood 2012: 10, 29; Malim 1948: passim; McConnell 1985: 7-8; Turner 2015: $1 \mathrm{ff}$; Warner 1946: $10 \mathrm{ff}$. 


\section{PRIVATE SCHOOLS IN SOUTH AFRICAN LEGAL HISTORY}

the first principles of the Latin language, pugilistic exercises, and the society of his fellowboys would be of the greatest benefit to the boy. His father objected that he was not rich enough to send the child to a good public school; ... but all these objections disappeared before the generous perseverance of the Marquis of Steyne. His lordship was one of the governors of that famous old collegiate institution called the Whitefriars. It had been a Cistercian Convent in old days ... . Henry VIII, the Defender of the Faith, seized upon the monastery and its possessions, and hanged and tortured some of the monks who could not accommodate themselves to the pace of his reform. Finally, a great merchant bought the house and land adjoining, in which, and with the help of other wealthy endowments of land and money, he established a famous foundation hospital for old men and children. An extern school grew round the old almost monastic foundation ... and all Cistercians pray that it may long flourish.

Of this famous house, some of the greatest noblemen, prelates, and dignitaries in England are governors: and as the boys are very comfortably lodged, fed, and educated, and subsequently inducted to good scholarships at the University and livings in the Church, ... there is considerable emulation to procure nominations for the foundations. It was originally intended for the sons of poor and deserving clerics and laics; but ... [t]o get an education for nothing, and a future livelihood and profession assured, was so excellent a scheme, that some of the richest people did not disdain it ... . Rawdon Crawley, though the only book which he studied was the Racing Calendar, and though his chief recollections of polite learning were connected with the floggings which he received at Eton in his early youth, had that

... reverence for classical learning which all English gentlemen feel, and was glad to think that his son was to have a provision for life, perhaps, and a certain opportunity of becoming a scholar.

In the course of a week, young Blackball had constituted little Rawdon his fag, shoe-black, and breakfast toaster; initiated him into the mysteries of the Latin Grammar, and thrashed him three or four times; but not severely. The little chap's good-natured honest face won his way for him. He only got that degree of beating which was, no doubt, good for him; and as for blacking shoes, toasting bread, and fagging in general, were these offices not deemed to be necessary parts of every young English gentleman's education? ... Rawdon marvelled over his [son's] stories about school, and fights, and fagging. ... He tried to look knowing over the Latin grammar when little Rawdon showed him what part of that work he was "in". "Stick to it, my boy," he said to him with much gravity, "there's nothing like a good classical education! Nothing!"

The same process is described in EM Forster's novel The Longest Journey (1907):

Sawston School had been founded by a tradesman in the seventeenth century. It was then a tiny grammar-school in a tiny town, and the City Company who governed it had to drive half a day through the woods and heath on the occasion of their annual visit. In the twentieth century they still drove, but only from the railway station; and found themselves not in a tiny town, nor yet in a large one, but amongst innumerable residences ... which had gathered round the school. For the intentions of the founder had been altered ... instead of educating the "poore of my home", he now educated the upper classes of England. The change had taken place not so very far back. Till the nineteenth century the grammar-school was still composed of day scholars from the neighbourhood. Then two things happened. Firstly, the school's property rose in value, and it became rich. Secondly, ... it suddenly emitted a quantity of bishops. The bishops, like the stars from a Roman candle, were all colours, and 


\title{
DM PRETORIUS
}

\begin{abstract}
flew in all directions, some high, some low, some to distant colonies, one into the Church of Rome. But many a father traced their course in the papers; many a mother wondered whether her son, if properly ignited, might not burn as bright; many a family moved to the place where living and education were so cheap, where day-boys were not looked down upon, and where the orthodox and the up-to-date were said to be combined. The school doubled its numbers. It built new class-rooms, laboratories and a gymnasium. It dropped the prefix "Grammar". ... And it started boarding-houses. It had not the gracious antiquity of Eton or Winchester, nor, on the other hand, had it a conscious policy like Lancing, Wellington, and other purely modern foundations. ... It aimed at producing the average Englishman, and, to a very great extent, it succeeded.
\end{abstract}

As the concluding sentence of the Thackeray extract quoted above indicates, public schools' curricula traditionally focused on the classics, especially Latin and Greek grammar and literature. ${ }^{5}$ Gradually, though, it came to be appreciated that "education" had to extend beyond academic instruction to "gentlemanly virtues", leadership, "moral character" and the ideal of mens sana in corpore sano ${ }^{6}$ Not infrequently these attributes were imparted in a maladroit manner. Aspects of the methodology adopted by public schools of yore certainly seem unduly spartan to modern sensibilities; even a century ago that system reminded one writer of "quasi-Norman feudalism". ${ }^{7}$ That notwithstanding, so distinctive - if not revered - an institution did the public school become in the upper echelons of British (especially English) society and culture that, over time, a whole corpus of public school fiction developed. The most famous, but not the first (and not the most verisimilar or the most meritorious from a literary perspective) of these prose works was Thomas Hughes' Tom Brown's Schooldays (1857), which is set at Rugby School in the time of its renowned headmaster, $\mathrm{Dr}$ Thomas Arnold (who is generally regarded as the father of the English public school in its Victorian incarnation). It is testimony to the social standing of public schools that references to such schools, fictional and real, abound in works of literature produced in England and elsewhere. ${ }^{8}$

Although "public schools" are often treated as one monochromatic category, many of them developed their own idiosyncratic traditions, games and, in some cases, even argot - so much so that it was said that the ritual of a great public school was "as intricate and finely woven as a Beethoven sonata". Even houses within schools microcosms of the greater institutions - acquired unique customs and identities. As

5 Gray 1913: 85ff, 111-112; Levi 1865: 395ff; Seldon \&Walsh 2013: 15; Shrosbree 1988: 25-33;Turner 2015: $71 \mathrm{ff}$. On the social role of the classics in English public schools, see Waquet 2001: 212-218; Jones 2008: 26ff; Stephen 2018: 247; Brooke-Smith 2019: 117-119.

6 Brooke-Smith 2019: 142; Levi 1865: 340; Mangan 2000: passim; O’Neill 2014: passim; Russell 1823: 203ff; Seldon \& Walsh 2013: 19-23; Shrosbree 1988: 7-8; Turner 2015: 91ff.

7 Gray 1913: 168.

8 See, for example, Kilner First Going to School, or the Story of Tom Brown and His Sisters (1804); Dickens Nicholas Nickleby (1839 - Dotheboys Hall) and David Copperfield (1849 - Dr Strong's School); Thackeray The Newcomes (1854 - Grey Friars); Farrar Eric, or, Little by Little (1858 Roslyn); Baines Reed The Fifth Form at St Dominic's (1881); Malan Schooldays at Highfield House (1898); Kipling Stalky \& Co (1899 - the College); Richards Billy Bunter 
such, generations of public-school boys retained an abiding sense of allegiance to house, school, God and country (in that sequence, it was sometimes said). ${ }^{9}$

In England, "public schools" came to be distinguished from "private schools", which were privately-owned ventures run for profit, with the owner often also being the principal. By contrast, "public schools" were incorporated associations, not operated for financial gain. ${ }^{10}$ But schools of the type that in England are known as "public schools" have historically been called "private schools" in South Africa, even though there were significant parallels between them, and even though many South African "private schools" deliberately modelled themselves on the English "public schools" (as, indeed, did not a few South African state schools). ${ }^{11}$

\section{Private schools in South African legal history}

South Africa, as we know it today, is an agglomeration of four polities, amalgamated in 1910 to constitute the Union of South Africa. ${ }^{12}$ These were the Colony of the Cape of Good Hope, the Zuid-Afrikaansche Republiek (which became Transvaal Colony after the Second Anglo-Boer War, 1899-1902), the Orange Free State (which became Orange River Colony after that war), and Natal. There were marked differences between the education systems in these four territories. For present purposes, we shall focus on the two largest territories, the Cape and the Transvaal. In both instances, the provision of public (state) education was deficient, especially

(1908 - Greyfriars); Wodehouse Tales of St Austin's (1903), Mike at Wrykyn and Enter Psmith (1909 - Wrykyn and Sedleigh); Harcourt Burrage The Idol of St Moncreeth (1925); Waugh Decline and Fall (1928 - Llanabba); Hilton Goodbye Mr Chips (1934 - Brookfield); Blyton Malory Towers (1946); Buckeridge Jennings (1950 - Linbury Court); Willans Nigel Molesworth (1953 - St Custard's); Spark The Prime of Miss Jean Brodie (1961); Waugh Charles Ryder's Schooldays (1982 - Spierpoint); Rowling Harry Potter (1997 - Hogwarts). On the phenomenon of British public school fiction, see Brooke-Smith 2019: 11-15, 62-71; Musgrave 1985: passim; Quigly 1982: passim; Reed 1964: passim; Reed 1974: passim; Richards 1988: passim; Stephen 2018: $171 \mathrm{ff}$; Turner 2015: 178, 202. American examples include Salinger The Catcher in the Rye (1951 - Pencey); Knowles A Separate Peace (1959 - Devon); Tartt The Secret History (1992 Hampden); Wolff Old School (2003). South African examples include Smith Leon (1963 - Clan College); Blakemore Maasdorp (1932) and Keurboslaan (1941); Wessels Die Nuwe Seun (1964); Van de Ruit Spud (2005).

9 Brooke-Smith 2019: passim; Farmer 1900: passim; Gray 1913: 197-198, 360; Heywood 1899: 286; Mangan 2000: 146ff, 170; Marples 1940: passim; McConnell 1985: 8; Mount 2013: passim; Seldon \& Walsh 2013: 16; Stephen 2018: 24-28; Taylor 2019: 17, 100, 104.

10 Gray 1913: 33; Smurthwaite 1981: 2; Turner 2015: 48; Hayman v Governors of Rugby School (1874) LR 18 Eq 28; Dilworth v Commissioner of Stamps [1899] AC 99; The General Committee for Ackworth School v Betts (1915) 6 TC 642; The Girls' Public Day School Trust v Ereaut [1931] AC 12.

11 See Ashley 1971: 34, 38; Heilbuth 1992: passim; Peacock 1972: passim; Randall 1982: passim; Smurthwaite 1981: 1-4.

12 South Africa Act, 1909 (9 Edw VII c 9); Hahlo \& Kahn 1960: $118 \mathrm{ff}$. 


\section{DM PRETORIUS}

(but not only) for black children; in both instances, private schools (notably church schools) played a major role in remedying the deficiencies. By the 1930s, there was "an enormous benevolent empire" of church schools, which employed nearly 8000 teachers and taught in excess of 370000 children. By 1953, 4827 of the 5819 schools in the entire country, teaching about 800000 children, were being run by the churches. The Catholic Church alone was running 662 schools, educating 111361 pupils. ${ }^{13}$

\section{The colony / province of the Cape of Good Hope}

The shortcomings of the education system during the Dutch administration of the Cape (1652-1806) are well documented and require little expatiation. At least until the Batavian interlude (1803-1806), education was much neglected by modern standards. This was so in the case of the relatively privileged white colonist children, and even more so in the case of Khoi and slave children. Such education as was provided by the authorities was largely restricted to the Cape peninsula. ${ }^{14}$ Further afield, it was left to Christian missionaries to provide a rudimentary level of education. In 1737, Moravian brothers set up a mission school for Khoi children at Baviaanskloof (Genadendal). It only remained in operation until 1743, but was reopened in 1792. In 1799, the London Mission Society (LMS) began to work in the eastern frontier districts among Khoi, San and Xhosa people. By 1803, forty children were attending the LMS mission school at Bethelsdorp. But the education administered at these mission stations was a double-edged sword: it was inextricably bound up with the adoption of Christian and European culture and values, with the concomitant subversion of indigenous cultures and social structures. ${ }^{15}$

By 1806, when the Cape became a British colony, education was in a dire state. In 1812, the Governor, Sir John Cradock, began to implement measures designed to organise education on a more systematic basis. He instituted "free schools", along the lines of English charity schools, intended to provide the "lower orders" with Christianity, morality, and the Protestant work ethic. Cradock's successor, Lord Charles Somerset, continued the free school programme. In principle, these schools were open to all races. In practice, enrolment at English-medium schools was mostly white, while students at schools that used Dutch as medium of instruction often

13 See Abraham 1984: 91; Allen 2007: 43; Collins \& Gillespie 1994: 29; Landis 1962: 489; Macquarrie 1956: 33-34; Ntantala 1960: 46; Sundkler \& Steed 2004: 823

14 Babb-Bracey 1984: 36; Behr 1952: 64ff; Board of Education 1901: 3ff; Du Toit 1940: 41ff; Leonie 1965: 44ff; Le Roux 1998: 95ff; Loram 1917: 46ff; Malan 1922: 1ff; Malherbe 1925: 49ff; Marais 1957: 171, 269; Squelch 1997: 23.

15 Babb-Bracey 1984: 51ff; Behr 1952: 86ff; Leonie 1965: 53; Mahuma 2004: 45-46; Mashale 2009: 18-19; Molteno 1988: 48-51; Sales 1975: 42ff; Saule 1985: 31ff; Sundkler \& Steed 2004: 66, 325-326, 331-339. 
were racially mixed. Free schools established at Uitenhage and Wynberg during Somerset's era eventually evolved into Muir College and Wynberg Boys' High School, both of which still exist. On the whole, however, the free school initiative foundered, mainly due to a shortage of qualified teachers. ${ }^{16}$

In an effort to address this problem, an ecumenical group of Cape Town clergymen set up a non-denominational school in 1829. From this initiative developed the South African College School (SACS) and the University of the Cape of Good Hope. ${ }^{17}$ This augured well for education in Cape Town, but the situation in the country districts remained dismal. In 1839, Sir George Napier appointed James Rose Innes as Superintendent General of Education and mandated him to implement a new threetier system devised by the astronomer, Sir John Herschel. First-class schools provided primary and secondary education (including Latin, Greek and French), and in some cases tertiary to boot. ${ }^{18}$ Scottish teachers were appointed to start first-class schools at Wynberg, Stellenbosch, Paarl, Worcester, George, Grahamstown, Port Elizabeth, Graaff-Reinet, Uitenhage and Somerset East. In smaller towns, secondclass schools provided only primary education. English was the medium of instruction in the first- and second-class schools. In the rural areas, third-class mission and farm schools taught basic literacy and arithmetic. These schools could obtain grants-inaid. By 1859, there were nineteen so-called established schools and 178 so-called aided schools in the colony. The official policy remained that government schools were accessible to all classes and races without distinction. De facto, however, many schools were reserved for white children. In the poorer areas, schools were integrated; white children attended mission schools in the countryside. ${ }^{19}$

Thus, public education in the Cape Colony acquired a more solid footing. Meanwhile, the foundations of "private" education were also being laid. In 1848, the first Anglican Bishop of Cape Town, Robert Gray, founded St George's Grammar School, partly to serve as a feeder for the Cathedral choir. The next year, Gray opened a Collegiate School, charging fees of $£ 50$ per annum, which would become known as Diocesan College (Bishops). In 1855, the inaugural Anglican Bishop of

16 Babb-Bracey 1984: 80-82; Behr 1952: 177ff; Board of Education 1901: 11-16; Coates 1975; Du Toit 1940: 56ff, 64-75; Hawthorne \& Bristow 1993: 18-20, 44; Leonie 1965: 63-66; Le Roux 1998: 158ff; Malan 1922: 6-16; Malherbe 1925: 58-68; Peacock 1972: 167; Thomson 1961; Veitch 2016: passim.

17 Board of Education 1901: 16-17; Du Toit 1940: 76; Linnegar 1979: passim; Walker 1929: passim.

18 SACS, Diocesan College, Victoria College (Stellenbosch), Huguenot Seminary (Wellington), Gill College (Somerset East), Grey Institute (Port Elizabeth), St Andrew's College (Grahamstown) and Graaff-Reinet College eventually acquired the status of university colleges: Board of Education 1901: 50; Metrowich 1929: 5-8; Walker 1929: 31-32, 35. On the Huguenot Seminary, founded in 1874, see, in general, Duff 2006; Pierson 1894.

19 Babb-Bracey 1984: 82ff; Behr 1952: 191ff; Board of Education 1901: 18ff; Chase 1843: 142-143; Cross 1994: 81; Du Toit 1940: 82-88; Leonie 1965: 65-67; Malan 1922: 7ff; Malherbe 1925: 72ff; Marais 1957: 270-271; Ferguson \& Immelman 1961: passim; Ruskin 2004: passim. 


\section{DM PRETORIUS}

Grahamstown, John Armstrong, founded St Andrew's College. Other schools in Cape Town followed, such as St Joseph's College (founded by the Marist Brothers in 1867), Springfield Convent (Dominican Sisters, 1871) and St Cyprian's Diocesan School for Girls (Anglican, 1871). ${ }^{20}$

By that time, Christian churches had embarked on a process of establishing schools at mission stations stretching from Namaqualand through the Overberg and the Karoo to the Colony's eastern frontier and "British Kaffraria". ${ }^{21}$ In time, this process produced prominent private schools for black pupils. There were particularly good mission schools in the eastern districts, primarily (but not exclusively) intended for Thembu and Mfengu children. One of the oldest of these schools was at Clarkebury, a Wesleyan mission station near Mthata, dating back to the 1830s. By 1847, its dayschool was being attended by eighty students. It grew into a large boarding school with impressive grounds and buildings. ${ }^{22}$ The Glasgow Missionary Society founded Lovedale, at Alice in the Ciskei, in 1841. It was a multiracial school until the 1890s, and offered a liberal education (including cricket) equal to that at any British public school. ${ }^{23}$ Shawbury mission school, a Wesleyan institution, also dated back to the 1840s. ${ }^{24}$ Healdtown, a Wesleyan school near Fort Beaufort, was established in 1855. It was to become, with Lovedale, the most celebrated of the Cape mission schools. ${ }^{25}$ The next year, Bishop Armstrong started St Matthew's Anglican mission school at Keiskammahoek. ${ }^{26}$ Lesseyton Methodist mission school, near Queenstown, was opened in 1857. ${ }^{27}$ The Free Church of Scotland's Blythswood Institution was set up at Butterworth in 1877, funded largely by money raised by the local Mfengu community. ${ }^{28}$ And in 1858, Bishop Gray had founded Zonnebloem College in Cape Town. It was "a sort of black Haileybury", where the children of Xhosa chiefs, such as Sandile and Maqoma, were educated and taught to play cricket. Two sons of the Sotho king, Moshoeshoe, attended Zonnebloem, as did a son of the Rolong chief, Moroka. ${ }^{29}$

It was not only in Cape Town and environs and in the eastern districts of the Cape Colony that famous mission schools came to be centred. Perhaps the most

20 Broekmann \& Weldon 1996: passim; Chase 1843: 144-145; Coyne 1997: passim; Currey 1955: passim; Gardener 1997: passim; McIntyre 1950: passim; Pascoe 1901: 783; Peacock 1972: 33, 223, 241; Poland 2008: passim.

21 See Church Missionary Society 1846: $21 \mathrm{ff}$; Hoole 1847: 345ff.

22 Coggin 1930: 8ff; Hoole 1847: 361; Skota 1932: 398; Whiteside 1906: 292-295.

23 Duncan 2000: passim; MacKenzie 2007: 109-113; Saule 1985: 99ff; Schoeman 2015: 184; Stewart 1894: passim; Shepherd 1940: passim; Sundkler \& Steed 2004: 326, 355, 359.

24 Hoole 1847: 363; Skota 1932: 409.

25 Skota 1932: 399; Sundkler \& Steed 2004: 359; Webster 2013: passim; Whiteside 1906: 283-285.

26 Goedhals 1979: 18; Pascoe 1901: 785; Sundkler \& Steed 2004: 353.

27 Duncan 2018: 1; Whiteside 1906: 285-286.

28 Gibbs 2017: 12, 77-78; MacKenzie 2007: 114; McGregor 1977; Rodger 1977; Saule 1985: 121; Sundkler \& Steed 2004: 359.

29 Hodgson 1975: passim; Hodgson 1987: passim; Odendaal 2003: 22-27; Pascoe 1901: 784; Sundkler \& Steed 2004: 356. Haileybury was a public school in England where pupils were prepared for the civil service, especially in India: Malim 1948: 43; McConnell 1985: $165 \mathrm{ff}$. 
notable example of an excellent mission school situated in the more remote regions was the LMS's Moffat Institution at Kuruman in Bechuanaland, founded in 1879 as a seminary, and reincarnated as a school, Tiger Kloof Educational Institution, at Vryburg in $1904 .{ }^{30}$

Arguably, the growth of schools modelled on English public schools was integral to the process of empire-building. These "British-type schools became hegemonic institutions that sought to create subjects who possessed modes of interpreting the world that were loyal to colonial interests and ... to the class relations ... that underpinned such interests". ${ }^{31}$ As it transpired, though, many of the leaders of the anti-colonial independence movement, both in South Africa and elsewhere on the continent, were products of these selfsame schools. ${ }^{32}$

In 1863, a commission chaired by Mr Justice Watermeyer recommended that the "established" or "free" schools (which were badly administered and were losing pupils to private schools) be phased out, and that "aided" schools be developed and named "undenominational public schools". A new Education Act ${ }^{33}$ provided for three types of schools, namely undenominational public schools, mission schools and aborigines schools, each in the first, second and third class. By 1873, there were 346 aided mission schools and aborigines schools, and 169 public schools. ${ }^{34}$

The Dutch Reformed Church (DRC) imported Scottish teachers. The inaugural rector of Stellenbosch (later Paul Roos) Gymnasium, set up by the DRC's Theological Seminary in 1866, was a Scotsman named WEW Braid. ${ }^{35}$ The first headmaster of the first-class public school established at Paarl in 1868, where the white population was predominantly Dutch-speaking, was a Scotsman, the Reverend George Jeffries. $\mathrm{He}$ was succeeded in 1876 by the Reverend Dr Thomas Walker from Edinburgh, who later became a professor at Victoria College. Members of the DRC's Strooidakkerk congregation were instrumental in founding and administering this school (later known as Paarl Boys' High School). The establishment of this school indicates that many Dutch-speaking burghers of Paarl felt that the local gymnasium, founded by GWA van der Lingen in 1858, with Dutch as its medium of instruction, did not satisfy the educational demands of that day and age, and that there was a need for an English-medium school. It was probably a sign of the times that, in 1872, the

30 Hoole 1847: 371; Sundkler \& Steed 2004: 429ff; Volz 2014: passim; De Gruchy 2009: 80-81. Tiger Kloof's alumni included Sir Seretse Khama, Sir Ketumile Masire and Ruth Mompati.

31 See, for example, Jones 2008: 102ff; Kenway et al 2017: 1ff; Molteno 1988: 50.

32 Gibbs 2017: 11, 18; Winterbach 1994: 1.

33 Act 13 of 1865. See Board of Education 1901: 33, 37 and 42; Du Toit 1940: 96ff; Le Roux 1998: 178ff, 191-192; Loram 1917: 49-50; Malan 1922: 7-8; Malherbe 1925: 95ff; Malherbe 1939: 4; Walker 1929: 34-35.

34 Babb-Bracey 1984: 97, 106; Board of Education 1901: 44

35 Brummer 1918: 139; Du Toit 1940: 102. 


\section{DM PRETORIUS}

gymnasium itself became an English-medium school. ${ }^{36}$ In due course, there was a relatively straight historical line between first-class schools such as these and the socalled Model C schools of the 1980s and 1990s.

By the 1890s, only a third of European children of school age in the Cape Colony were attending school. Some 10000 white children were attending mission schools; a third of the total number of white children at school in the Cape Colony attended mission schools in which there was no colour bar. ${ }^{37}$ The authorities perceived this state of affairs with disquiet, so the School Board $\mathrm{Act}^{38}$ made it compulsory for white children between the ages of seven and fourteen to attend school, and "encouraged" parents of coloured children to send their children to school, but did not enforce this. Thus the level of education of white children was raised, but black children were left behind. But for the existence of church-run mission schools, the situation would have been a great deal worse. In this sense, these private schools contributed to combating the increasing racial inequality in education, and in filling the vacuum that arose from the colonial administration's sins of omission in respect of the education of black children. Still, the situation remained woeful. In 1917, Lovedale was the only black first-class school in the Colony (and the only high school in South Africa preparing "native" students for matriculation to university on a systematic and sustained basis). ${ }^{39}$

The Education Ordinance of $1921^{40}$ introduced a degree of regulation of private schools, which had to be registered with the Superintendent General, who was authorised to inspect any private school "for the purpose of ascertaining the condition of such school, including the premises, furniture and equipment, the nature of the instruction given and the manner in which the school is conducted". This law expressly provided for separate schools for "European" and "non-European" children in the Cape Province, making school attendance compulsory for the former category, but not for the latter. ${ }^{41}$ The 1921 Ordinance was superseded by the Education

36 De Villiers 1924: 38ff; Du Toit 1940: 103; Mentz 1941: 360ff; Goosen 1984: 16; Engela 1992: 6-9.

37 Babb-Bracey 1984: 84; Cape of Good Hope 1891: 4-7, 13, 213-214; Cross 1994: 81; Malan 1922: 3; Marais 1957: 271; Smurthwaite 1981: 209.

38 Act 35 of 1905. See Colonial Secretary v Molteno School Board (1910) 20 CTR 159; Molteno School Board v Molteno Municipal Council 1912 AD 772; Wellington Boys' High School Committee v Wellington School Board 1920 CPD 522; Malan 1922: 8; Malherbe 1939: 4; Le Roux 1998: 201ff; Squelch 1997: 26. Bedwell 1909: 331 described this Act as "the first statutory enactment that deals seriously with the subject of education" in the Cape Colony.

39 Loram 1917: 129-130. Even by the 1940s, the provincial authorities had little involvement in education for black children: see Cape Provincial Administration v Xabanisa 1941 AD 203 at 208.

40 Cape Consolidated Education Ordinance 5 of 1921, ch 25. See MEC for the Eastern Cape Department of Education v Playways Pre-Primary School [2018] ZAECELLC 4 par $121 \mathrm{ff}$.

41 See Cape Provincial Administration v Xabanisa 1941 AD 203; De Gouveia v SuperintendentGeneral of Education 1954 (3) SA 1009 (C) 1012A-G. See, also, Superintendent-General of Education (Cape) v Fife 1955 (2) SA 279 (A). 
Ordinance of $1956,{ }^{42}$ section 240 of which largely replicated the provisions of the 1921 Ordinance pertaining to private schools. It stated expressly that these provisions applied to private schools "for European children", thus enforcing racial segregation in respect of private schools' admissions policies.

\section{The Zuid-Afrikaansche Republiek / Transvaal}

In the early years of the Boer settlement of the Transvaal, education was "haphazard and uncertain". There was only perfunctory state involvement in education for white children; no provision was made for formal education of black children. The general perception was that education was not the concern of the state, and that it was the domain of the established church, the Dutch Reformed Church. Only from 1859 did the state assume responsibility for education of white children. A School Commission was set up, and a framework for education was created, but this was largely in the realm of aspiration. By 1864, there were only seven state-employed teachers in the ZAR. ${ }^{43}$

Under the presidency of TF Burgers (1872-1877), a new education statute ${ }^{44}$ created an education department. Schools were divided into three categories according to their location and their curricular scope, namely: (i) "ward schools", usually one-teacher farm schools providing elementary instruction; (ii) "district schools", situated in bigger towns, providing more advanced elementary education; and (iii) a gymnasium at Pretoria, where secondary and higher education were to be provided. This system, too, failed. By 1877 (when the ZAR was annexed by Britain), only about 8 per cent of white children in the ZAR were attending school. ${ }^{45}$

During the British annexation, a new education law was enacted. ${ }^{46} \mathrm{~A}$ system of state aid to private schools was instituted as a parallel to the existing system of state schools (such as it was). This facilitated the founding of Pretoria schools, such as Prospect Seminary, Loreto Convent (Catholic, 1878), St Birinus Diocesan School (Anglican, 1879) and St Etheldreda's School, later known as St Mary's Diocesan School for Girls (Anglican, 1879). By 1880, there were eleven government schools and twelve state-aided private schools in the Transvaal. ${ }^{47}$

42 Cape Education Ordinance 20 of 1956. See MEC for the Eastern Cape Department of Education $v$ Playways par 134ff.

43 Bot 1951: 3; Le Roux 1998: 302-316; Lugtenburg 1925: 62ff; Malherbe 1925: 224ff; Squelch 1997: $29 \mathrm{ff}$

44 Act 4 of 1874.

45 Council of Education 1916: 3; Bot 1951: 7; Le Roux 1998: 316-320; Lugtenburg 1925: 89ff; Malherbe 1925: 241-249.

46 Act 10 of 1880. See Bot 1951: 12; Le Roux 1998: 320-323; Lugtenburg 1925: 116ff; Malherbe 1925: 250-255.

47 Addison 1979: passim; Anon 1913: passim; Lugtenburg 1925: 110, 118, 124-125, 137, 172; Randall 1982: 97; Smurthwaite 1981: 74, 133; 8 Jun 2018 Pretoria News. 


\section{DM PRETORIUS}

The First Anglo-Boer War, in which the British were defeated at Majuba (1881), led to restoration of an autonomous ZAR, under British suzerainty. In 1881, SJ du Toit was appointed as Superintendent of Education. Yet another Education Act was passed the following year. ${ }^{48}$ It contemplated that the state's primary role in education was to incentivise private initiative by means of subsidies or grants-in- aid. Schools were classified as either elementary, intermediate or higher institutions, with the value of grants ascending according to the level of the school. Whereas the 1874 Act had provided that instruction was to be in Dutch or English, at the will of parents, the 1882 Act restricted subsidies to schools using Dutch as medium of instruction. However, this restriction was not enforced rigidly: until 1892, English- medium schools experienced little difficulty in obtaining subsidies. Although the administration of education improved under Du Toit's superintendence, the standard of education remained mediocre. ${ }^{49}$

The discovery of gold on the Witwatersrand in 1886 provided impetus to the growth of education in the ZAR. The first government school in Johannesburg was opened in July 1887. The Dutch Reformed Church set up two others schools in Johannesburg during the course of $1887 . .^{50}$

Catholic religious orders played a leading role in launching schools in Johannesburg. In July 1886, the Rt Reverend Odilon Monginoux OMI, the first Prefect Apostolic of the Transvaal, acquired land in central Johannesburg for a chapel, a convent and a girls' school. The Bishop of Natal, Monsignor Charles Jolivet OMI, sent six French Holy Family sisters to take charge of this school, which opened on 1 October 1887 . By the end of 1887 , the convent had seventy-five pupils. The school moved to Doornfontein in 1895, and became known as the East End Convent. In 1905, the Holy Family sisters also founded Parktown Convent School (now Holy Family College) ${ }^{51}$

The Reverend John Darragh, the first Anglican priest to be stationed on the Rand, was a pioneer of education in Johannesburg. He initiated St Mary's College for Girls, which commenced instruction in the hall of St Mary's Church, Eloff Street, on 6 January 1888. The school later moved to Belgravia and then to Waverley. At the same time, Darragh set up St Mary's School for Boys as a choir school for St Mary's Church. Based on the model of British grammar schools, the school had 160 pupils by 1890, when the principal was the Reverend HB Sidwell (later Bishop of George). ${ }^{52}$

48 Act 1 of 1882. See Lugtenburg 1925: $130 \mathrm{ff}$.

49 Basson 1956: 89ff; Bot 1951: 15; Council of Education 1916: 3-4; Horton 1968: 6; Le Roux 1998: 324-329; Malherbe 1925: 259-266; Marais 1961: 55; Ploeger 1952: 40ff; Smurthwaite 1981: 176; Venter 1950: 25-26.

50 Venter 1950: 32-34.

51 Basson 1956: 137; Smurthwaite 1981: 80-82, 90; Venter 1950: 35-40.

52 Grainger 2013; Smurthwaite 1981: 134; Sundkler \& Steed 2004: 404ff; Venter 1950: 44-50. 
Marist Brothers' Sacred Heart College, near Joubert Park, started with fourteen boys in October 1889. "Here there was not only good schooling, but cricket, football and other team games were encouraged. The moral standing was high." The school acquired such a good reputation that some officials of the staunchly Protestant ZAR government enrolled their sons at this Catholic school. By 1897, Marist Brothers' had 500 pupils. It was Johannesburg's premier boys' school..$^{53}$

On 11 April 1890, Chief Justice (later Sir John) Kotzé laid the foundation stone of St Michael's College, an Anglican Church school in Commissioner Street. The driving force behind the creation of St Michael's was the vicar of St Mary'sChurch, the Reverend Darragh. A Jewish school was opened in 1890, and the Deutsche Schule was started in Edith Cavell Street in 1897. ${ }^{54}$

In 1892, the education law was amended to provide that all teachers in aided schools had to be members of a Protestant church; schools also could not receive subsidies in respect of Jewish and Catholic pupils. All textbooks had to be in Dutch. These changes led to some schools losing their grants. School enrolments in the bigger towns (where there were concentrations of English-speaking, Catholic and Jewish people) dropped. In response to these developments, a group of uitlanders established the Witwatersrand Council of Education (WCE) in 1895. The WCE's objects were to promote elementary education "suited to all nationalities and creeds" and to counter the exclusive use of Dutch as medium of instruction. In 1897, the WCE bought St Michael's College and renamed it Jeppestown Grammar School the progenitor of Jeppe High Schools for Boys and Girls. ${ }^{55}$

According to a report published by the WCE in 1895, there were fifty-five schools for uitlander children in Johannesburg and environs. Of the 187 teachers, only fortysix held professional qualifications. It was estimated that nearly a third of white children of school-going age were not attending school. This dire situation persisted: by 1897-1898, fewer than fifty white children (out of a total school attendance of 15 000) in the entire ZAR were in or above Standard VI, and only forty per cent of the 687 white teachers in the country had any formal qualifications..$^{56}$

By 1896, there were seven mission schools for black children in Johannesburg. The Reverend Darragh founded two of these schools: St Cyprian's School (started in 1890) and Perseverance School (1891). Both schools were initially granted a government subsidy on the understanding that they would enrol only white children. When inspections revealed that black children were in attendance, the subsidies

53 Oct 1929 Maristonian; Paola 1967: 56-58, 114; Venter 1950: 40-42.

54 Hawthorne \& Bristow 1993: 199; Venter 1950: 51, 79.

55 Basson 1956: 97ff, 137ff; Council of Education 1916: 4-7; Horton 1968: 7, 15, 29-31; Lugtenburg 1925: 221, 243; Malherbe 1925: 267ff, 290ff; Marais 1961: 56; Ploeger 1952: 73, 76ff, 101ff; Venter 1950: 84ff.

56 Council of Education 1916: 5; Horrell 1970: 25; Horton 1968: 22-26; Malherbe 1925: 290-291; Venter 1950: 174. 


\section{DM PRETORIUS}

were withdrawn. Although Perseverance eventually succumbed to the pressures of impecuniosity, St Cyprian's somehow survived. ${ }^{57}$ Darragh continued his educational endeavours through his involvement in the establishment of St John's Collegein 1898. ${ }^{58}$

However, the progress on the schools front over the preceding decade nearly came to naught when the Second Anglo-Boer War broke out in October 1899. It caused an exodus of civilians from the ZAR and necessitated the closure of most schools. There was a hiatus in educational activities until civilians returned once the British had taken control of Johannesburg and Pretoria. Schools reopened from 1901 onwards, while the guerrilla war continued in the veld.

Once Lord Milner's colonial administration had taken power, his "kindergarten" set about implementing education policies quite different from those of the defunct ZAR. Whereas the pre-war Boer government (which had not been favourably disposed towards English-language private schools) had paid grants to such schools, subject to strict conditions, the British authorities deprived such schools of any subsidisation. This policy proceeded from a determination to have all education under state control to facilitate the dominance of British culture and ideology over those of the Boers. Vast resources were invested in undenominational state schools offering free or heavily subsidised tuition and superior facilities that made them more alluring than private schools. A by-product, if not the objective, of the Milner system was to undermine private schools..$^{59}$

So came into existence the famous "Milner schools": King Edward VII School (KES), the Jeppe, Pretoria and Potchefstroom boys' high schools, and Johannesburg, Jeppe and Pretoria girls' schools. (The Parktown schools followed later.) There was no doubting the need for good schools such as these, but the policy was antagonistic, in effect if not in intention, to private education. It resulted in the closure of St Birinus School in Pretoria, and nearly caused the demise of St John's College (saved from extinction only by the charitable intervention of the Anglo-Catholic Community of the Resurrection, which ran the school from 1905 until 1934) ${ }^{60}$ In Johannesburg, the struggle between the state and the ecclesiastical schools found expression in a protracted dispute about the location of the state schools, culminating in the proceedings of the Secondary Education Commission. ${ }^{61}$

The Education Ordinance of $1903^{62}$ introduced comprehensive regulation of private schools. Private schools were required to be registered, and to submit quarterly returns to the Transvaal Education Department (TED) of the number,

57 Behr 1952: 287ff; Cross 1986: 53; Horrell 1970: 26; Venter 1950: 51-56.

58 Lawson 1968: passim; Randall 1982: 99.

59 Basson 1956: 144ff; Bot 1951: 55; Council of Education 1916: 10-11; Cross 1986: 35; Le Roux 1998: 341; Malherbe 1925: 315ff; Smurthwaite 1981: 177; Venter 1950: 408.

60 Agar-Hamilton 1928: 80-81; Lawson 1968: 30-32; Malim 1948: 109-111; Randall 1982: 43, 102; Venter 1950: 381; Winter 1970: 33.

61 Report of the Transvaal Secondary Education (Johannesburg) Commission (1906).

62 Ordinance 7 of 1903. See Manson \& Bisschop 1905: 407; Bedwell 1909: 446; Squelch 1997:31. 
names and qualifications of teachers employed and of pupils' attendance. Teachers were required to hold certificates, and private schools were subject to inspection by the TED. The Ordinance contemplated that "native" education would be provided mainly through state-aided mission schools, which were to emphasise training for industrial and manual labour. By implication, the principle of racially separate schools was introduced. A survey of mission schools disclosed that only 10 per cent of African children of school age were enrolled in schools. In a letter to the Superintendent of Education, a Swiss missionary charged that the education policy set out "to make the native an English speaking boy or girl for the use of the white man, rather than a man capable of thinking by himself and of leading intelligently his life". ${ }^{63}$

In 1905, the Earl of Selborne succeeded Milner as Governor of the Transvaal and Orange River colonies. The Selborne Minute (Nov 1905), loosened the shackles of the centralised bureaucratic system imposed by Milner, by allowing white local communities more influence in educational matters through the creation of school committees and district school boards. ${ }^{64}$ After General JC Smuts became Minister of Education in 1907, a new Education $\mathrm{Act}^{65}$ expressly decreed racially segregated schools. It was specifically provided that a "coloured" child may not be admitted to a school for white children. ${ }^{66}$ School attendance became compulsory for white children between the ages of seven and fourteen. ${ }^{67}$ Private schools remained subject to regulation. A private school could be closed by the Director of Education if it appeared to him that the school was being conducted in a manner "calculated to be detrimental to the physical, mental or moral welfare of the pupils attending thereat". ${ }^{6}$ Although this very subjective criterion posed a potential threat to the existence of private schools, in practice the departure of Milner, the arrival of the relatively liberal Selborne and the appointment of Smuts as Minister of Education signified a slight relaxation of the colonial administration's suspicious attitude towards private schools.

The rapprochement between the authorities and private schools was symbolised by the fact that Lord Selborne visited St John's College in 1907 and 1924, as did Smuts in $1928 .{ }^{69} \mathrm{~A}$ modus vivendi developed between the state and private schools. It endured until the apartheid era, when the state adopted an attitude of undisguised

63 Annual Report by the Commissioner for Native Affairs (1903) A10-A11; Cross 1994: 83-84; Cross 1986: 55-60.

64 Bot 1951: 61; Le Roux 1998: 343-344; Malherbe 1925: 325-335; Macintosh v Pretoria School Board \& Sunnyside School Committee 1908 TS 872.

65 Act 25 of 1907. See Babb-Bracey 1984: 85; Bedwell 1909: 477-478; Bisschop 1908: 471-473; Bot 1951: 63; Cross 1994: 84; Cross 1986: 64; Le Roux 1998: 351-358; Malherbe 1925: 331-341.

66 Section 29.

67 Section 19.

68 Chapter 8, s 36.

69 Lawson 1968: 69, 191, 208; Winter 1970: 39-40. 


\section{DM PRETORIUS}

animosity towards private schools, especially in the Transvaal. The MEC for Education, Dr T Wassenaar, articulated the government's attitude: "Private schools really no longer have the right to exist. We regard the government school as the proper school." On another occasion, he said: "[G]overnment schools are the best for our children. There is also the advantage that there can be a greater degree of uniformity ... and that no difference in thought will result.... Private schools are only a relic today, a relic of former times." In the 1970s, the hostility found expression in disputes between the state and private schools about the admission of black pupils to historically white private schools. ${ }^{70}$

We have seen how the churches played an instrumental role in establishing schools for black children in the Cape. The same pattern emerged in the Transvaal, where the state made no provision for schools for black children until after the AngloBoer War, and then only on a limited and segregated basis. Milner articulated the British objective: "I do not mean that ['natives'] should be educated like Europeans, for their requirements and capacities are very different, but that they should be trained and develop their natural aptitudes for their own good and that of the community." The role of Milner's administration in "native" education was restricted to the subsidisation of mission schools. By 1912, there was not a single government high school for "native" children in the entire Transvaal; by 1917, there was only one such school. So it was incumbent on the churches to answer the educational needs of the "native" population. This they did - to an extent. In 1906, there were 177 unaided mission schools in the Transvaal with an enrolment of 8492 pupils, and 197 aided schools with 11730 pupils. By 1915, there were 267 aided mission schools in the Transvaal, educating 15428 pupils. $^{71}$

A striking example was St Peter's School. The Community of the Resurrection, which ran St John's College, founded St Peter's Theological College in Rosettenville, south of Johannesburg, in 1904 as a seminary for training black Anglican clergymen. The Community also started St Agnes' School for African girls (1908) and St Peter's School for African boys (1922) in Rosettenville. St Peter's was the only secondary boarding school for Africans in the Transvaal. It had a "grandness of atmosphere"; it became known as a "Black Eton". Its pupils went on to acquire prominence in the emerging black middle class; in the 1940s and 1950s they became a veritable "who's who" in the influential and respected ANC Youth League. St Peter's alumni included men as diverse as Fikile Bam, Jonas Gwangwa, Lucas Mangope, Hugh Masekela, Todd Matshikiza, Joe Matthews, Congress Mbata, Zephania Mothopeng, Bertram Moloi, Es'kia Mphahlele, Duma Nokwe and Oliver Tambo. After having graduated from Fort Hare University, Tambo returned to teach physics at St Peter's

70 Heilbuth 1992: 1; Randall 1982: 151, 186; Smurthwaite 1981: 187-195.

71 Cross 1986: 38-39; Leonie 1965: 75-78; Loram 1917: 63, 65. 
(1943-1947). St Peter's School was closed in 1956 after the Bantu Education Act ${ }^{72}$ had made state funding of mission schools subject to stringent conditions devised to promote apartheid policies. (Most mission schools elected to close down rather than accept these conditions. The Catholic, Seventh-Day Adventist, United Jewish Reform Congregation and Congregational churches and, to an extent, the Anglican Church, continued without state aid.) St Peter's Theological College remained in existence; Archbishop Emeritus Desmond Tutu studied there, graduating in 1960. ${ }^{73}$

Many other private schools for black children in the Transvaal were set up by church bodies at a time when the state declined to do so. In many of these schools the calibre of education was poor, with teachers lacking adequate qualifications. The highest level to which pupils could aspire in many schools was Standard III or IV. However, several schools flourished against all odds, with little or no state aid. The first of these schools was set up by the Hermannsburg Evangelical Lutheran Society at Phokeng, near Rustenburg, in 1857. ${ }^{74}$ Other good mission schools and colleges in the Transvaal included Kilnerton teacher training and theological school near Pretoria (established by Wesleyan missionaries in 1884) $;{ }^{75}$ Grace Dieu College near Pietersburg (Anglican, 1906); ${ }^{76}$ Lemana Training Institution near Elim in the northern Transvaal (Swiss Mission Society, 1906) ${ }^{77}$ Botšhabelo Training Institution near Middelburg in the eastern Transvaal (Berlin Mission Society, 1906) $7^{78}$ and Medingen mission school near Modjadjiskloof in the northern Transvaal (Berlin Mission Society, 1881). ${ }^{79}$ Most of these institutions were closed down during the socalled Bantu education era, when control of "native" schools was transferred from the provincial governments to the national government. "Native" schools not under direct government control had to be registered; registration could be refused if the responsible Minister believed that the school was "not in the interests of the Bantu people ... or is likely to be detrimental to the physical, mental or moral welfare of the pupils". It was a criminal offence to conduct an unregistered private school for "native" children. ${ }^{80}$

72 Act 47 of 1953.

73 Allen 2007: 63ff; Callinicos 2004: 67ff; Collins \& Gillespie 1994: 26-27; Landis 1962: 495; Malan 2008: 50ff; Mphahlele 1959: 124ff; Ntantala 1960: 46; Skota 1932: 411; Sundkler \& Steed 2004: 415; Wilkinson 1992: 212ff; Winterbach 1994: passim; Woeber 2000: 183-214.

74 Behr 1952: 281ff; Bot 1951: 155; Sundkler \& Steed 2004: 367, 419-420. See, also, Cross 1994: 85; Mahuma 2004: 56, 74; Mathabatha 2005: passim.

75 Sundkler \& Steed 2004: 407. Kilnerton's alumni include former Deputy Chief Justice Dikgang Moseneke, John Marks, Oliver Matsepe, Miriam Makeba and Lilian Ngoyi. Stanley Mogoba and Sefako Makgatho taught at Kilnerton.

76 Mokwele 1988: passim; Winterbach 1994: 64.

77 Mashale 2009: 20; Seroto 1999: 44-45, 77; Skota 1932: 401.

78 Seroto 1999: 83ff; Sundkler \& Steed 2004: 390.

79 Hahlo \& Kahn 1960: 811-812; Landis 1962:494-496.

80 Hahlo \& Kahn 1960: 811-812; Landis 1962:494-496. 


\section{The Orange Free State and Natal}

The authorities in the OFS and Natal were less hostile to private schools than in the Transvaal, but did not encourage the development of private schools for black children, even though the need for such schools was clamant: there was not one government high school for "native" children in the OFS and Natal by 1912. In Natal, private schools set up for white children included Hilton College (nondenominational, 1872), Holy Family Convent (1875), St Charles Grammar School (Order of Mary Immaculate, 1875), Durban Collegiate (non-denominational, 1877), St Anne's Diocesan School for Girls (Anglican, 1877), Michaelhouse (Anglican, 1896), St John's Diocesan School for Girls (Anglican, 1897) and Maris Stella Convent (Holy Family sisters, 1899). ${ }^{81}$ Notable mission schools for African children in Natal included Adams College at Amanzimtoti (Congregationalist American Board of Commissioners for Foreign Missions, 1853), Inanda Seminary for Girls (American Board, 1869), St Francis College, Marianhill (Catholic Trappists, 1882) and John Langalibalele Dube's Ohlange Institute (American Board, 1901). ${ }^{82}$ There were a few mission schools for Indian children, for example St Aidan's (Anglican, 1886) and St Anthony's (Holy Family, 1888). ${ }^{83}$ In the OFS, schools such as St Andrew's School (Anglican, 1863), Greenhill Convent (Holy Family, 1871) and St Michael's School for Girls (Anglican, 1874) were set up for white children, as were schools like St Philip's, Good Shepherd and St Patrick's for black children. ${ }^{84}$

\section{The "independence" of private schools in South African legal history}

During the colonial period, governmental regulation of private schools varied from one territory to another. In the Cape, regulation was largely limited to the conditions attached to grants-in-aid. ${ }^{85}$ This laissez-faire attitude extended to admissions policies. From the late 1800s, however, racial segregation became institutionalised in public

81 Babb-Bracey 1984: 123ff; Barrett 1969; Board of Education 1901: 197ff; Hattersley 1945: passim; Leonie 1965: 72; Le Roux 1998: 207; Loram 1917: 53ff, 72; Malherbe 1925: 181ff; Malim 1948: 101ff; Pascoe 1901: 786; Peacock 1972: 81; Smurthwaite 1981: 72-73, 113; Squelch 1997: 27.

82 Babb-Bracey 1984: 151, 251-256; Du Rand 1990: passim; Gibbs 2017: 12; Grant 1957: passim; Hoole 1847: 365; Khandlhela 1993: passim; Moore 1990: 21ff, 37-38; Skota 1932: 395-407; Sundkler \& Steed 2004: 363ff, 823; Wood 1972.

83 Hawley 2008: 65.

84 Damant 1963: passim; Gunn 1905: 27ff; Leonie 1965: 79ff; Le Roux 1998: 251ff; Le Roux 2016 : 125; Loram 1917: 65; Malherbe 1925: 351; Malherbe 1939: 4; O’Connor 1974: 8ff; Smurthwaite 1981: 73-74, 113, 131-132. In 1907, there were about one hundred church and mission schools in the Orange River Colony, educating 8933 black children, but receiving a total subsidy of only $£ 1700$ from the state: Schoeman 2015:183.

85 Chase 1843: 144. 
schools, and by the 1920s a segregation policy was also applied to private schools. In the ZAR, subsidies were available to private schools, including mission schools, but only if they were operated on a racially segregated basis. After the Anglo-Boer War, private schools in the Transvaal were subjected to regulation through registration requirements. Similar requirements were gradually extended to other territories, but were not as stringent in the Cape as they were in the Transvaal. ${ }^{86}$

The state's "hands-off" approach towards private schools (especially in the Cape Province) was reflected in the judiciary's attitude as articulated in a number of cases dealing with the question whether private church schools fell to be regarded as "public schools" (effectively state schools) for purposes of exemption from municipal rates assessments. There was a long line of cases dealing with questions of this nature. ${ }^{87}$ These cases were decided with reference to particular provincial ordinances and municipal by-laws, rather than national legislation. As such, they did not articulate general principles applicable to all private church schools across the board. Nevertheless, they do provide a general indication of the official approach adopted towards private schools.

The most significant of these cases was the decision of the Appellate Division of the Supreme Court in Marist Brothers Trustees v Port Elizabeth Municipality. ${ }^{88}$ This case was concerned with the question whether St Patrick's School in Port Elizabeth, a private school run by the Marist Brothers, was a "public school" for purposes of exemption from municipal rates. This judgement elucidates the laissez-faire attitude towards private schools in the Cape. Innes CJ and De Villiers JA outlined the historical development of public education in the Cape Colony, including the three-tier system of public schools (undenominational, mission and aboriginal schools), referred to above. The integration of these public schools in the state education system, and their control by the state, was contrasted with the legal status of private schools, such as $\mathrm{St}$ Patrick's. These private schools, said Innes CJ, were "outside the system". They were managed by churches or religious bodies, received no grants, and "were not subject to state inspection or control". Compared to state schools, which were supervised by public authorities, "schools like St Patrick's stood in a very different position" in that "they were free from public supervision; and whatever practical policy they might find it expedient to adopt, they were legally free in important respects in which aided schools were bound" ${ }^{89}$ In law there was "no limit to the power of exclusion" that these private schools had in respect of their admissions policies. Although a school

86 See, generally, Behr 1952: 200ff, 315ff; Cross 1994: 81-82; Squelch 1997: 35-36.

87 See, for example, Council of The Diocesan College v Rondebosch Municipality (1901) 18 SC 112;

Dominican Convent v South Shepstone Local Board (1923) 44 NLR 391; Alice Municipality v

Lovedale Missionary Institution (1938) 44 EDL 160; Wellington Municipality v Huguenot Seminary 1939 CPD 15; De Aar Divisional Council v Convent of the Holy Cross 1952 (1) SA 495 (C).

881924 AD 487.

89 At $496-498$. 


\section{DM PRETORIUS}

like St Patrick's was "subject to the exercise by the Superintendent-General of the authority to inspect private schools" for purposes of monitoring pupils' compulsory school attendance, it was "[i]n no other sense, and to no greater extent, ... liable to Government supervision and inspection". A school such as this was "free from any trace of pubic control". ${ }^{90}$ De Villiers JA stated that St Patrick's, which had "never been under the control of any school board", was "the property of and is controlled and managed by" the Institute of the Marist Brothers, and the school's "curriculum is in the discretion of the Institute". ${ }^{91}$

Thus, private church schools in the Cape were largely free from governmental supervision, and could determine their own admissions policies (within the racial constraints of the time) and curriculum. However, the narrow definition of the term "public school" in Cape legislation meant that private schools did not qualify for the benefit of exemption from municipal rates. So favourably disposed towards private church schools were the provincial authorities in the Cape that, shortly after the Appellate Division's decision in the Marist Brothers case, the definition of the term "public school" was amended to include any school not conducted for private pecuniary benefit. The courts construed the amended definition to mean that private church schools not operated for financial gain were to be treated as "public schools", and so became exempt from municipal rates. ${ }^{92}$

However, in the apartheid years official attitudes towards these schools changed, as emerged in the Appellate Division's decision in Swart NO v De Kock. ${ }^{33}$ This matter dealt with the question whether the Transvaal Provincial Council was entitled to enforce, by ordinance, mother-tongue instruction in private schools. A Flemish girl enrolled at Loreto Convent in Pretoria was receiving instruction through the medium of English. The TED had notified the Mother Superior of the Convent that the girl's home language had been determined to be Afrikaans and that the school's conduct in educating her in English contravened the Ordinance. The Mother Superior and the Bishop of Pretoria had then obtained an order in the Transvaal Provincial Division of the Supreme Court to the effect that the Ordinance had been enacted in excess of the powers of the Provincial Council, which was empowered by section 85 of the South Africa Act to make ordinances relating to "education other than higher education". It was contended that these words did not extend to private schools, and that section 85

90 At 491-493.

91 At 500-501, 506. See, also, Springfield Public School v Baumgarten (1906) 16 CTR 22 at 25, where it was intimated that the managing body of a private school would have "absolute control" of that school.

92 See Christian Brothers College v Kimberley Municipality 1935 GWLD 37; Christian Brothers College v Kimberley Municipality 1936 AD 220; Marist Brothers v Port Elizabeth Municipality 1948 (4) SA 698 (A).

93 Swart NO \& Nicol NO v De Kock; Swart NO \& Nicol NO v Garner 1951 (3) SA 589 (A). 
conferred no power on the provinces to legislate as to the language to be used in private schools. On appeal, this contention was rejected by Centlivres CJ:

$[\mathrm{O}]$ nce it is clear, as I think it is clear that the State has the right to compel parents to send their children to school to be educated, it also has the right to prescribe how the children should be educated. It is, in my view, entitled to say that the provision in regard to compulsory education shall not be regarded as having been satisfied in the case of a child sent to a nonState-aided private school unless that private school in educating that child uses methods approved by the State..$^{4}$

On this basis it was held that, although private schools had not been brought "completely under control" of the state, there was no reason why a Provincial Council "should not ordain that the child must be educated through the medium of its home language, whether that education takes place in a public or private school". The word "education" in section 85 was construed as including "to a certain extent education in a private school". ${ }^{95}$ Fagan and Van den Heever JJA concurred, the latter stating that the fact that "the state hardly interfered with private schools prior to Union [was] an accident of history" ${ }^{96}$ However, Schreiner JA (with whom Hoexter JA agreed) dissented:

Whatever regulations may properly be introduced in respect of private schools, and I assume for the purposes of the argument that such regulations may cover methods of teaching, ... the teachers in such schools as well as the children attending them are entitled to be protected against regulations that infringe the freedom to use either [official] language. ... I have approached the consideration of this case from the angle of the parent's right to make any arrangement that he wishes for the satisfactory education of his child. The State may provide safeguards to ensure that a proper standard of education is given to the child. But it is not entitled to ... require that, where the parent chooses to send his child to a private school, the child must there be taught through a particular one of the official languages. ... [N]o practical or theoretical considerations could operate to require restriction of the free choice of a parent who wishes at his own expense to send his child to a private school..$^{97}$

Commenting on this "great constitutional case" in which judicial opinion had been "curiously divided", a youthful Ellison Kahn (a KES old boy) noted that "the

94 At 605G-H. Centlivres CJ was educated at SACS, UCT and New College, Oxford: see E K 1966: passim; Corder 1984: 31.

95 At $609 \mathrm{~B}-\mathrm{H}$. Mother-tongue instruction was a slightly bizarre notion in circumstances where in excess of 40 per cent of white South African children came from bilingual homes: Fleisch 2007: passim. See, also, De Bruin v Director of Education 1934 AD 252.

96 At $620 \mathrm{H}$. In the Cape, the authorities had historically not required private schools to comply with official policy regarding the medium of instruction: see Cape of Good Hope 1908: vii-viii and xiii-xiv.

97 At 617G-618A, 618H. Schreiner JA was educated at Rondebosch BHS, SACS, UCT and Trinity College, Cambridge: Kahn 1980: 566. Hoexter JA was educated at Grey College and Emmanuel College, Cambridge: Corder 1984: 33. 


\section{DM PRETORIUS}

majority Judges drew no distinction" between private and public schools, whereas "Schreiner and Hoexter, JJ.A., did draw a very sharp distinction between the two types of school". He continued:

If the present reviewer be permitted to make a choice between the two views ... he would fall on the side of the minority. To him the majority opinion contains a fatal flaw .... With due respect, it is submitted that the judgment of Schreiner, JA, will go down in history as one of the great dissenting opinions; of the company of those two immortal minority judgments ... of Lord Shaw of Dunfermline ... and Lord Atkin. ${ }^{98}$

Despite the virtues of Schreiner JA's dissenting judgement, it is apparent from a comparison of the Appellate Division's decisions in Marist Brothers and Swart NO $v$ De Kock that, by the 1950s, private schools were subject to a much more intrusive level of state regulation than had historically been the case. Throughout the apartheid era, private schools enjoyed less independence than previously, and their autonomy to govern their own affairs was significantly impaired.

\section{Racial segregation institutionalised in South African schools}

In the insidious manner described above, racial segregation became integral to the South African education system. Unlike in the United States of America, where the Supreme Court's decision in Brown v Board of Education of Topeka ${ }^{99}$ proscribed statutory racial segregation in state schools, our judiciary did not intervene to rectify the situation that had arisen here. A case originating in the remote Gordonia region of the northern Cape presented an opportunity for our courts to intervene, but thrice they declined to do so.

The factual situation that gave rise to Moller v Keimoes School Committee ${ }^{100}$ was not uncommon in the Cape Province of a century ago. The applicant, Carel Moller, was a general dealer in the town of Keimoes. His wife, Magdalena Moller (née Green), was the daughter of "a pure bred Englishman" (Mr Moller's description of his father-in-law) ${ }^{101}$ or "a white man of pure breed" (per Hopley J). Mrs Moller's mother was "an aboriginal native of this country". ${ }^{102}$ In South African racial terminology,

98 Kahn 1951: 358-359. See, also, McWhinney 1954: 45, 58-59.

99347 US 483 (1954). Ironically, Brown was effectively overturned by the US Supreme Court itself in Parents Involved in Community Schools v Seattle School District No 1511 US 701 (2007). See Isaacs 2010: 364ff.

1001911 CPD 673. This section is an expanded extract from my PhD thesis, The Functus Officio Doctrine in South African Administrative Law (University of the Witwatersrand, 2004) 188ff. See, also, Babb-Bracey 1984: 84; Loveland 1999: 134ff; Suzman 1960: 343.

101 Replying affidavit, Appellate Division court bundle $44 \S 8$. Searle J used the same description: 1911 CPD 673 at 686

1021911 CPD 673 at 683; AD bundle 59. Lord de Villiers said that "we may fairly take it that her mother was a black or native woman": 1911 AD 635 at 642. However, Searle J said "we must assume that her mother was a coloured woman": 1911 CPD 673 at 686; AD bundle 61-62. 
Mrs Moller was “coloured". So Mr and Mrs Moller's children were "quadroons" (a term used by counsel for the respondents). ${ }^{103}$ Their children did not attend the local third-class undenominational public school, the pupils of which were exclusively white. However, Mr Moller received accounts for payment of School Board rates. On 6 December 1910, he sent an objection to the Upington divisional council, saying that he failed to see why he should pay the rates "as I have not the same right for schooling my children as some parties have". The divisional council secretary (who also happened to be the chairman of the Gordonia School Board) replied by letter dated 21 December 1910: "The School Board Act says that all Europeans are liable for school rates .... Y You can send your children to the Keimoes Public School as long as you pay the school fees."104

So, in January 1911, Mr Moller took his two children to be enrolled at the public school. He showed the principal (the second respondent) the letter from the divisional council's secretary. The principal then admitted the children, and Moller paid a term's school fees in advance. A week later, Moller received a letter from the principal, returning the school fees as he had "received instructions from the Local School Committee to refuse your children to attend the Public School any longer". ${ }^{105}$ Moller also received a letter from the school committee, notifying him that they had been informed by the Superintendent of Education "dat het in de belange van de School is eenig kind te weigeren op te nemen, tegen wien zij eenig objectie hebben moge. Zij hebben dus besloten, \& de School-Meester gelast Uwe kinderen niet verder op te nemen". ${ }^{106}$ When the school refused to reinstate the two children, Moller launched proceedings in the Cape Supreme Court, seeking an order compelling the respondents to admit his children to the school.

The school committee averred that several parents of white pupils had complained about the admission of Moller's children to the school; some had withdrawn their children in protest. The committee opposed admission of the Moller children (who, so they claimed, were "very noticeably coloured") because it was "against the interests of the School to allow bastard children therein" as there would then "be no white children left" in the school, and "the European child will be entirely ousted, and will receive no education". ${ }^{107}$ The School Board secretary said that "once the principle of admitting coloured and bastard children in the Public Schools is allowed, all the

1031911 CPD 673 at 679. If Mrs Moller's mother was "coloured" rather than "native", as Searle J thought, then the Moller children would have been "octoroons" and not "quadroons" (to use that archaic, if not derogatory, terminology).

104 Annexures "A" and "B" to the founding affidavit, AD bundle 7, 8; replying affidavit, AD bundle $42 \S 2$.

105 Annexure "E" to the founding affidavit, AD bundle 11.

106 Annexure "F" to the founding affidavit, AD bundle 12 ("that it was in the interest of the school to refuse to receive any child against whom they might have any objection. They had therefore decided and directed the principal no longer to admit your children").

107 Keimoes school committee's answering affidavit, AD bundle $20-21$ § 12-16. 


\section{DM PRETORIUS}

Schools of the district would be in danger of being overrun by coloured children". ${ }^{108}$ The School Board alleged that "the class of Europeans who intermarry with coloured women are mostly of low character and consequently their children cannot but have an undesirable influence over white children if they be allowed to mix" ${ }^{109} \mathrm{Mr}$ Moller took issue with claims of this nature: ${ }^{110}$

I deny that the men who married coloured women are mostly of low class, most of them having done so [due to] the fact that during the [previous] regime in ... this District prior to annexation, no man could become a landed proprietor unless he were a burgher, and he could not become such unless he were either a coloured man or had married a coloured woman, the country having been given to the Bastards by the late Colonial Government. Many of these men hold extensive properties and many of their coloured wives have been thoroughly educated and are superior to many Europeans.

He said that many of those who objected to his children's presence in the school "have no better status than I have, on the contrary many of them are very low class poor whites, and their children may be seen daily associating with coloured and native children as companions". ${ }^{111}$ The Corporal in charge of the Cape Mounted Police at Keimoes deposed to a supporting affidavit:

I deny that the Applicant's children are noticeably coloured. I often see children bathing in the river and Applicant's son strips quite white. ... [A]t the recent general vaccination done by the District Surgeon ... at which I assisted, the son [of one of the objecting citizens] was classed as a coloured child while the children of Applicant were classed as Europeans ... . Applicant's children would pass for Europeans where they are not known. ${ }^{12}$

In the Cape Supreme Court, the matter came before Maasdorp JP. To him, the question was whether the fact that Moller's children were "not of pure European extraction" disentitled Moller from claiming as of right that they be admitted to the school, even though the 1905 School Board Act did not provide "in express terms for the establishment of schools for European children exclusively". ${ }^{113}$ That notwithstanding, the Judge President thought that the Act contemplated the existence of separate schools for children "of European parentage or extraction" and evinced a "clear intention" that "children of other than European extraction shall only attend schools established for such children." Thus, Moller was not entitled to have his children admitted to the school. Turning to the question whether the children could

108 Gordonia School Board secretary's affidavit, AD bundle $37 \S 6$.

109 Annexure to affidavit of School Board secretary, AD bundle 39.

110 Replying affidavit, AD bundle $44 \S 8$.

111 Replying affidavit, AD bundle $45 \S 9$.

112 Affidavit of Corporal Harry James Skipper, AD bundle 46-47.

113 1911 CPD 674-675; AD bundle 52. As explained above, the subsequent Education Ordinance 5 of 1921 (C) expressly provided for separate schools for "European" and "non-European" children in the Cape Province. 
be expelled from the school having been already admitted, Maasdorp JP declined to order specific performance of the contract between Moller and the school. ${ }^{114}$

On appeal to the full bench of the Cape Supreme Court, it was contended for Moller that the School Board Act did not talk about pure European children, and that his children were "more European than anything else". Buchanan J said that in South Africa "coloured people are generally understood to be those whose parents are not both white, but it is difficult to say exactly where the line should be drawn". The Act distinguished between those "who have coloured blood in their veins" and those who do not. Moller's children were not "of European parentage, because one quarter of the blood in their veins was coloured". ${ }^{115} \mathrm{He}$ held that, although there was nothing to prevent a school board from admitting coloured children into schools established for white children, a parent of coloured children had no right to force the board to admit his children to such a school. In the absence of such a right, and in the absence of mala fides or want of reasonable grounds for the committee's actions, the court would not grant mandamus upon the school committee. ${ }^{116}$

Hopley J concurred. He said that the words "of European extraction" should be read as though they were "of pure European extraction". In his view, it was not the policy of the Act "that children of pure European extraction should be associated as schoolmates with children of mixed or pure native descent". Although a school committee could admit children who were not "of pure European extraction", in casu there was no indication that the committee had not acted bona fide and to the best of their discretion in the interests of the school. ${ }^{117}$ Searle $\mathrm{J}$ said that, although there was "no section of the Act which distinctly says [so] in unqualified terms",

114 At 676-677; AD bundle 53-54. Christian George Maasdorp went to school at Graaff-Reinet and Grey College, Bloemfontein. He held an MA from the University of the Cape of Good Hope. He was called to the Bar by the Inner Temple in 1871 and was admitted to the Cape Bar in the same year. He was Attorney General of the Transvaal during the British annexation (1877-1881), a judge of the Eastern Districts Court from 1885, and a judge of the Cape Supreme Court from 1896: Anon 1907: 129; Anon 1914b: 426.

1151911 CPD 681; AD bundle 56. In my PhD thesis, referred to above (n 100), I wrote that Buchanan J was Sir James Buchanan (apropos of whom, see F St L S 1933: 137). In fact, the Buchanan J who sat in the Moller case was Sir James' cousin, Sir Ebenezer John Buchanan: see Anon 1900: 109; Kahn 1999: 67-68; Van Niekerk 2013: 117-118.

116 At 682-683; AD bundle 57-58. When the author's grandfather was a junior schoolboy at Paarl Gymnasium soon after the Anglo-Boer War, he did not have coloured boys among his fellow pupils. However, in his senior years (1906-1910) at the first-class Boys' High School in Wellington (where the author's great-grandfather was the secretary of the school board, 1906-1921) he did count coloured boys among his fellows; the last "non-European" boys were removed from the school only in 1939. See Malan 1948: 10; Le Roux 2002: 16-33. A generation later, the situation had changed. When the author's grandfather was principal of the second-class public school and deputy chairman of the Coloured School Committee at Naauwpoort in the Great Karoo in the 1930 s and 1940s, the education of white and coloured children occurred on a completely segregated basis.

1171911 CPD 673 at 684-685; AD bundle 59-60. 


\section{DM PRETORIUS}

the "whole tenor" of the Act was "in the direction of drawing a clear distinction between the two sets of children and the two sets of schools". While it was not illegal to receive a "non-European" child into a school for "European" children, the Act allowed a school committee "legally to exclude one class of children from the other class of school". The Moller children were "not of European parentage, because their mother is admittedly coloured". The committee had acted bona fide in exercising its "inherent power ... to exclude any children, if this proved to be in the best interests of the school". ${ }^{118}$

Eventually, the matter came before the Appellate Division (sitting in Cape Town, as it sometimes did in those days). ${ }^{119}$ Schreiner QC, appearing for Moller, argued that the School Board Act should not lightly be presumed to take away existing rights (as it would if construed in the manner adopted by the court a quo, in that there had never previously been any legal restriction on the right of black children to attend public schools in the Cape). He also argued that the Moller children were "of European extraction" on both sides, and that the interests of the school could not be allowed to prejudice the individual children. ${ }^{120}$ The Appellate Division gave short shrift to these arguments. Lord de Villiers CJ held that the Act envisaged the establishment of separate public schools for children of European parentage or extraction and for other children. There was a "principle of separation for purposes of education", and the Keimoes school was intended for children of European parentage. ${ }^{121}$ Turning to the fact that Moller had been assured by the divisional council's secretary that he could send his children to the school, the Chief Justice held that it was a case of great hardship on Moller, but the divisional council could not bind the school

1181911 CPD 673 at 685-687; AD bundle 61-62. Malcolm William Searle was a Bishops old boy. He graduated from St Catherine's College, Cambridge, before being admitted to the Bar at the Inner Temple. He was made a QC in 1893 and was elevated to the Cape bench in 1910: Anon 1885: 78; Anon 1919: 1.

119 The Appellate Division granted special leave to appeal on account of the matter's "public importance": Moller v Keimoes School Committee 1911 AD 585.

1201911 AD 635 at 636-638. William Philip Schreiner graduated from London University and Downing College, Cambridge. He was called to the Bar at the Inner Temple in 1882. He was elected MP for Kimberley in 1893, becoming Attorney General in Cecil John Rhodes' cabinet. He became Prime Minister of the Cape Colony in 1898. He was a vocal champion of native rights: Anon 1906: 117; Anon 1909: 7.

121 1911 AD 635 at 639-640. John Henry de Villiers (1842-1914) was a student at SACS. He became Chief Justice of the Cape Colony in 1873, aged thirty-one. He administered the oath of office to himself, à la Napoleon, thus averting a potential crisis arising from rumours that the more senior puisne judges, to whom he had been preferred for appointment, might refuse to administer the oath to him. He was knighted in 1877, and was made a member of the Judicial Committee of the Privy Council in 1896. In 1910, as Lord de Villiers of Wynberg, he was appointed Chief Justice of the Union of South Africa: Anon 1901: 1; Rose Innes 1914: 422; Bisschop 1915: 2; McGregor 1922: 52; Wessels 1931: 459; Kahn 2005: 263. 
committee. ${ }^{122}$ The question was whether Moller's children were "of European parentage or extraction". In this regard, Lord de Villiers stated the following:

When once it is established that one of a man's nearer ancestors ... was black, like a negro or Kafir, or yellow like a Bushman or Hottentot or Chinaman, he is regarded as being of other than European descent. ... [T] hese prejudices ... are ... deeply rooted at the present day among the Europeans in South Africa ... . We may not from a philosophical or humanitarian point of view be able to approve this prevalent sentiment, but we cannot, as judges ... ignore the reasons which must have induced the legislature to adopt the policy of separate education. ... It is regrettable that there should be this social chasm between the races, but it undoubtedly exists, and it has had its effect on legislation $[$ sic $] .{ }^{123}$

As, in terms of the Act, the school had been established for children of "European parentage or extraction", and as the Moller children were not of unmixed European parentage or extraction, they had no right to be admitted to the school, and so Lord de Villiers dismissed the appeal.

Innes J followed the same line of reasoning. In his view, the legislature's intention to bring about separate school accommodation could be clearly gathered from the wording of the Act. The Keimoes school had been established for white children of purely European extraction. This was a policy which might "inflict great hardship on deserving members of the community", especially in circumstances where "the machinery of the Act for the education of children of other than European extraction seems inadequate". But that was "what the Legislature has thought right to enact". ${ }^{124}$

Laurence $\mathbf{J}$ said that nothing prevented a public school from admitting children who were not of "European parentage or extraction", but it was under no obligation to do so. He acknowledged that the matter involved hardship for people like Moller, especially as only nine public schools for "non-European" children had been established in the Cape Province, and those were confined to a mere four districts: "[T] he problem of promoting the education of such children, beyond the curriculum of the mission schools, is one of which so far we have barely touched the fringe." All of that notwithstanding, the appeal had to fail. ${ }^{125}$ De Villiers JP and Sir John Kotzé JP came to the same conclusion. Kotzé JP said that "a certain amount of sympathy must naturally be felt for the innocent children", and acknowledged the argument that "the

122 At 641-642.

123 At 643-644.

124 At 645-650. James Rose Innes was educated at Gill College, Somerset East and UCT. He was called to the Cape Bar in 1878 and became a QC in 1890. Having been an MP and also Attorney General in two Cape cabinets, he was knighted in 1901 and appointed Chief Justice of the Transvaal in 1902. He was elevated to the Appellate Division upon its establishment in 1910 and served as Chief Justice from 1914 until 1927. After his retirement, he devoted the remaining years of his life to the cause of the Non-Racial Franchise Association: Anon 1902: 1; Wessels 1931: 461.

125 At 650-652. By implication, Laurence $\mathrm{J}$ acknowledged the role of mission schools in providing education for black children. 


\section{DM PRETORIUS}

prejudice of a section of the community should not be adopted as indicative of the law", but said that only the meaning of the legislature, as expressed in the Act, could be taken into account. ${ }^{126}$

And so, ultimately, nine judges had unanimously upheld the system of segregated public schools. "No excuse can lessen the harmful effects of this case, both in terms of the weight of precedent in future disputes involving race, and in the wider community, as an encouragement to just such racial prejudice as several judges purported to denounce." 127

History having a propensity to repeat itself, Moller's case found an echo in Seneque $v$ Natal Provincial Administration. ${ }^{128}$ The principal of a school for "European" children had admitted the appellant's three children to that school. The children had attended the school for periods ranging from four years to eighteen months, when a newly appointed principal required the appellant to provide proof that his children were of "pure" European descent for three generations on both sides. The appellant having been unable to provide such proof, his children had been excluded from the school. He had then applied for a mandamus compelling the respondent to re-admit his children to the school. Watermeyer JA (Tindall and Centlivres JJA concurring) held that the applicable regulations did not make the first principal's decision final and binding on the respondent, who could "set matters right" if it thought that he had been "wrong". De Wet CJ dissented, stating that the respondent, having delegated the discretion to decide the question of fact (ie whether the children were of "pure" European descent), to the first principal, was bound by his decision unless and until such decision was shown to be erroneous in fact or in law. ${ }^{129}$

126 At 656. Sir John Gilbert Kotzé LLB (London), another SACS old boy, was called to the Bar in 1874, having been proposed by Lord Halsbury. He was appointed a judge of the Transvaal High Court at the age of twenty-seven (which earned him the epithet "the boy Judge"). He became Chief Justice of the ZAR in 1881. In 1897, after a dispute about the courts' power to test laws against the Grondwet, he was removed from office by President Kruger. In 1900, he was appointed Attorney General of Southern Rhodesia, and in 1903 became a puisne judge of the Eastern Districts Court: Anon 1898: 58; Anon 1903: 101; Thompson 1954: 65-68. In 1904, he became Judge President of the Eastern Districts Court. He sat on the Cape bench from 1913, was knighted in the same year and was elevated to the Appellate Division in 1922: Corder 1984: 27, 37.

127 Corder 1984: 159. Also see Dyzenhaus 1991: 55-61, 82; Hahlo \& Kahn 1960: 812; McWhinney 1954: 71.

1281940 AD 149 at 160. See Corder 1984: 159-161. The situation that arose in Seneque's case was not without precedent in Natal: see Swartz \& Wassermann 2016: 881.

129 At 157. Nicolaas de Wet was educated at Victoria College, Stellenbosch, and Cambridge. He was admitted to the Cape and Pretoria Bars in 1896, soon becoming acting assistant State Attorney of the ZAR. During the Anglo-Boer War, he was General Louis Botha's military secretary. After the war, he returned to the Pretoria Bar, becoming a KC in 1912. A year later, he was appointed Minister of Justice in Botha's Union cabinet. He was appointed to the Transvaal bench in 1932 and to the Appellate Division in 1937. He became Chief Justice and a member of the Privy Council in 1939. After the death of Sir Patrick Duncan in 1943, De Wet served as OfficerAdministering the 
Although these cases, establishing the principle of racially segregated schools, were decided with reference to public schools, the same principle was enforced in respect of private schools. The matter was put beyond doubt by the Blacks (Urban Areas) Consolidation Act, ${ }^{130}$ which prohibited the admission of African pupils to any school outside the so-called locations. Accordingly, private schools were precluded from determining their own admissions policies - at least as far as race was concerned - and had to comply with apartheid laws in that regard. This form of state interference in the affairs of private schools eventually led to conflict between the authorities and private schools in the 1970s. Ultimately, Catholic private schools, such as Springfield Convent, Holy Rosary Convent and St Dominic's Priory, took the lead in defying educational apartheid in the mid-1970s. ${ }^{131}$

The National Party government continued to enforce control over private schools even as the apartheid edifice began to crumble in the 1980s. The "tricameral" Parliament enacted the Private Schools Act (House of Assembly), ${ }^{132}$ one stated object of which was to provide for "control over" private schools. Such control was exercised by means of registration regulations, ${ }^{133}$ which, in a circuitous way, retained the government's power to dictate admissions policies. ${ }^{134}$ Registration conditions also conferred power on government to control employment of teachers in private schools and to dictate the curriculum of private schools. ${ }^{135}$ In addition, provincial education departments were given broad powers to inspect various aspects of private schools' operations, and the Minister of Education was empowered to withdraw a private school's registration if the school was "managed or maintained in a manner ... that could, in his opinion, be harmful to the physical, intellectual or spiritual wellbeing of the pupils attending such school". ${ }^{136}$ Thus, tight control of private schools remained a hallmark of the apartheid regime till the very end.

Government for three years. After his retirement, he was a leader of the Torch Commando, which opposed the NP's proposed removal of coloured people from the common voters' roll. See Corder 1984: 41; Anon 1914a: 369; Tindall 1943: 275; Kahn 1960: 133.

130 Act 25 of 1945, s 9. See Squelch 1997: 40.

131 Heilbuth 1992: 72ff; Randall 1982: 191-192; Smurthwaite 1981: 229; Squelch 1997: 48ff.

132 Act 104 of 1986. See Squelch 1997: 55; MEC for the Eastern Cape Department of Education v Playways Pre-Primary School par 141.

133 Regulations Regarding the Registration of and Financial Grants to Private Schools, GNR 2281 GG 10502 of 31 Oct 1986 .

134 Regulation 2(2)(f) provided that registration of a private school was subject to the condition that the admission of pupils to such a school was subject to items 2 and 14 of Schedule 1 to the Republic of South Africa Constitution Act 110 of 1983 (the "tricameral" Constitution). This meant that admissions to private schools were regulated as an "own affair" by the white House of Assembly, which, in that manner, regulated such admissions on a racial basis: Squelch 1997: 56.

135 Regulations 2(2)(i) and 2(2)(1)(ii).

136 Regulations 4(1) and 6(2)(a). 


\section{DM PRETORIUS}

\section{$6 \quad$ Concluding remarks}

Education did not escape the ravages of South Africa's colonial and apartheid past. While a small number of good state schools can trace their origins back to the colonial era, public education during that era was inadequate; state education for black children, to the extent that it was provided at all, was deplorable. Private schools, especially church schools, made a significant contribution towards alleviating the shortcomings of public education. In the nineteenth century and the first half of the twentieth century, these schools enjoyed a significant degree of independence. In the Cape Colony (later the Cape Province) in particular, these schools had a high degree of freedom to carry on their educational activities without state regulation or interference. Even in the early 1900s, however, the state began to enforce racial segregation in private schools. During the apartheid era, state regulation of private schools intensified significantly, eroding the independence of these schools and undermining the extent to which they could have a beneficial social impact. This state of affairs has largely been rectified in the post-apartheid era, with the Constitution now guaranteeing the independence of private educational institutions. ${ }^{137}$

\section{Bibliography}

Abraham, G (1984) The Catholic Church and Apartheid, 1948-1957 (MA dissertation, University of Natal)

Addison, B (1979) Daughters of the King: The Story of St Mary's Diocesan School for Girls, 1879-1979 (Pretoria)

Agar-Hamilton, JAI (1928) A Transvaal Jubilee, Being a History of the Church of the Province of South Africa in the Transvaal (Guildford)

Allen, J (2007) Rabble-rouser for Peace: The Authorised Biography of Desmond Tutu (London)

Anonymous (1885) “Searle's Reports" Cape LJ 2: 78-81

Anonymous (1898) “The Transvaal Judiciary" Cape LJ 15: 58-64

Anonymous (1900) “The Hon Mr Justice EJ Buchanan” Cape LJ 17: 109

Anonymous (1901) "Sir JH de Villiers" SALJ 18: 1-10

Anonymous (1902) “Sir James Rose Innes” SALJ 19: 1-4

Anonymous (1903) “The Hon JG Kotze” SALJ 20: 101-110

Anonymous (1906) “The Hon WP Schreiner KC” SALJ 23: 117-120

Anonymous (1907) "The Hon CG Maasdorp" SALJ 24: 129-131

Anonymous (1909) “The Native question in South Africa” Spectator 10 July 1909

137 On the regulation of independent schools under the Constitution and the South African Schools Act, see Pretorius 2019: passim. 
Anonymous (1913) Rosmarine: A Story of Twenty-Five Years and a Sequel, Being a Chronicle of St Etheldreda's School, Pretoria (London)

Anonymous (1914a) "The Honourable NJ de Wet KC" SALJ 31: 369-372

Anonymous (1914b) "Recent judicial changes" SALJ 31: 426-427

Anonymous (1919) "Mr Justice Searle” SALJ 36: 1-4

Ashley, MJ (1971) "The education of white elites in South Africa" Comparative Education 7: $32-45$

Babb-Bracey, IPA (1984) The development of educational policy for Black Africans in South Africa, 1652-1948 (DEd thesis, University of Massachusetts)

Baines Reed, T (1881) The Fifth Form at St Dominic's (London)

Barrett, AM (1969) Michaelhouse, 1896-1968 (Pietermaritzburg)

Barter, A (1934) Stories of Pendennis and the Charterhouse, from Thackeray (London)

Basson, MA (1956) "Die Britse invloed in die Transvaalse onderwys, 1836-1907" in A Kieseret al (eds) Archives Year Book for South African History 19: 89-371

Bedwell, CEA (ed) (1909) Legislation of the Empire: Being a Survey of the Legislative Enactments of the British Dominions from 1898 to 1907 vol 2 (London)

Behr, AL (1952) Three Centuries of Coloured Education: Historical and Comparative Studies of the Education of Coloured People in the Cape and Transvaal, 1652-1951 (DEd thesis, Potchefstroom University)

Bisschop, WR (1908) "Review of legislation, 1907: Transvaal" J of the Society of Comparative Legislation 9: 465-476

Bisschop, WR (1915) “The Rt Hon Baron de Villiers of Wynberg, KCMG” J of the Society of Comparative Legislation 15: 2

Blakemore, S (1932) Die Meisies van Maasdorp (Pretoria)

Blyton, E (1946) First Term at Malory Towers (London)

Board of Education (1901) Special Reports on Educational Subjects Vol 5: Educational Systems of the Chief Colonies of the British Empire Cd 417 (London)

Bot, AK (1951) The Development of Education in the Transvaal, 1836-1951 (Pretoria)

Broekmann, E \& G Weldon (1996) There Are Stories to be Told: St Cyprian's School 1871-1996 (Cape Town)

Brooke-Smith, J (2019) Gilded Youth: Privilege, Rebellion and the British Public School (London) Brummer, NJ et al (1918) Gedenkboek van het Victoria-Kollege (Cape Town)

Buckeridge, A (1950) Jennings Goes to School (London)

Callinicos, L (2004) Oliver Tambo: Beyond the Engeli Mountains (Claremont)

Cape of Good Hope (1891) First Report and Proceedings, with Appendices, of a Commission Appointed to Enquire into and Report upon Certain Matters Connected with the Educational System of the Colony (Cape Town)

Cape of Good Hope (1908) Report of the Select Committee on Education Legislation (Cape Town) Chase, JC (1843) The Cape of Good Hope and the Eastern Province of Algoa Bay (London) 


\section{DM PRETORIUS}

Church Missionary Society (1846) Missionary Register: Survey of the Protestant Missionary Stations throughout the World in their Geographical Order (London)

Coates, PNA (1975) The History of Muir College (Uitenhage)

Coggin, K (1930) The Deathless Years: A Centenary Souvenir of Clarkebury Mission (Grahamstown)

Collins, CB \& RR Gillespie (1994) "Catholic education in South Africa: A history of compromise and coincidence" J for the Study of Religion 7: 21-47

Corder, H (1984) Judges at Work: The Role and Attitudes of the South African Appellate Judiciary, 1910-1950 (Cape Town)

Council of Education, Witwatersrand (1916) History of Council, 1896-1916 (Johannesburg)

Coyne, P (1997) Cross of Gold: The Story of St George's Grammar School (Kenilworth)

Cross, M (1986) The Foundations of a Segregated Schooling System on the Witwatersrand (MEd dissertation, University of the Witwatersrand)

Cross, M (1994) Culture and Identity in South African Education, 1880-1990 (PhD thesis, University of the Witwatersrand)

Currey, RF (1955) St Andrew's College, Grahamstown, 1855-1955 (Oxford)

Damant, D (1963) A Centenary History of St Andrew's School (Bloemfontein)

De Gruchy, J (2009) Christianity and the Modernisation of South Africa, 1867-1936 vol 2 (Pretoria)

De Villiers, FE (ed) (1924) In the Valley of the Berg, or the Romance of a South African Town (Paarl)

Dickens, C (1839) The Life and Adventures of Nicholas Nickleby (London)

Dickens, C (1849) The Personal History, Adventures, Experience and Observation of David Copperfield the Younger of Blunderstone Rookery (Which He Never Meant to Publish on Any Account) (London)

Duff, SE (2006) Head, Heart and Hand: The Huguenot Seminary and College and the Construction of Middle Class Afrikaner Femininity, 1873-1910 (MA thesis, University of Stellenbosch)

Duncan, GA (2000) “Coercive Agency”: James Henderson's Lovedale, 1906-1930 (DTh thesis, University of South Africa)

Duncan, GA (2018) “Lesseyton: A Wesleyan Methodist Missionary Society experiment in African industrial and theological education" Studia Historiae Ecclesiasticae 44: 1-19

Du Rand, SM (1990) From Mission School to Bantu Education: A History of Adams College (MA dissertation, University of Natal)

Du Toit, PS (1940) Onderwys in Kaapland, 1652-1939: 'n Historiese Oorsig (Pretoria)

Dyzenhaus, D (1991) Hard Cases in Wicked Legal Systems: South African Law in the Perspective of Legal Philosophy (Oxford)

E K (1966) "In memoriam: The Hon A v d S Centlivres" SALJ 83: 387-389

Engela, TW (1992) In die Paarl Groei 'n Boom: Geskiedenis van die Hoër Jongenskool Paarl, $1868-$ 1989 (Paarl)

Farmer, JS (1900) Public School Word-Book (London) 
Farrar, FW (1858) Eric, or, Little by Little (Edinburgh)

Ferguson, WT \& RFM Immelman (1961) Sir John Herschel and Education at the Cape 18341840 (Cape Town)

Fleisch, B (2007) "Social scientists as policy makers: EG Malherbe and the National Bureau for Educational and Social Research, 1929-1943” J of Southern African Studies 21: 349-372

Forster, EM (1907) The Longest Journey (London)

Gardener, J (1997) Bishops 150: A History of the Diocesan College, Rondebosch (Cape Town)

Gibbs, T (2017) Mandela's Kinsmen: Nationalist Elites and Apartheid's First Bantustan (Woodbridge)

Goedhals, MM (1979) Anglican Missionary Policy in the Diocese of Grahamstown under the First Two Bishops, 1853-1871 (MA dissertation, Rhodes University)

Goosen, D (1984) Die Geskiedenis van die Paarl First Class Public School, 1868-1901 (MA dissertation, Stellenbosch University)

Grainger, P (2013) St Mary's School, 1888-2013 (Johannesburg)

Grant, GC (1957) The Liquidation of Adams College (Durban)

Gray, HB (1913) The Public Schools and the Empire (London)

Gunn, H (1905) "Education in the Orange River Colony" in British Association, South Africa Contributions to Education in South Africa (Johannesburg): 27-31

Hahlo, HR \& E Kahn (1960) South Africa: The Development of Its Laws and Constitution (London)

Halsbury (2015) Laws of England vol 35 (London)

Harcourt Burrage, A (1925) The Idol of St Moncreeth: A School Story of Mystery, Humour and Sport (London)

Harwood, E (2012) England's Schools: History, Architecture and Adaptation (Swindon)

Hattersley, AE (1945) Hilton Portrait: South African Public School, 1872-1945 (Pietermaritzburg)

Hawley, JC (ed) (2008) India in Africa, Africa in India: Indian Ocean Cosmopolitanisms (Bloomington)

Hawthorne, P \& B Bristow (1993) Historic Schools of South Africa: An Ethos of Excellence (Cape Town)

Heilbuth, P (1992) An Analysis of the South African State's Policy with Respect to Private Schools: 1976 1990 (MPhil dissertation, UCT)

Heywood, GGT (1899) "Boys at public schools" in EH Pitcairn (ed) Unwritten Laws and Ideals of Active Careers (London): 286-297

Hilton, J (1934) Goodbye, Mr Chips (London)

Hodgson, J (1975) A History of Zonnebloem College, 1858-1870: A Study of Church and Society (MA dissertation, UCT)

Hodgson, J (1987) "Kid gloves and cricket on the Kei” Religion in Southern Africa 8: 61-91

Hoole, E (1847) The Year-Book of Missions: Containing a Comprehensive Account of Missionary Societies, British, Continental and American (London) 


\section{DM PRETORIUS}

Horrell, M (1970) The Education of the Coloured Community in South Africa, 1652-1970 (Johannesburg)

Horton, JW (1968) The First Seventy Years, 1895-1965, Being an Account of the Growth of the Council of Education, Witwatersrand (Johannesburg)

Hughes, T (1857) Tom Brown's Schooldays (London)

Hughes, T (1879a) "The public schools of England, part 1" North American Review 128: 352-371

Hughes, T (1879b) “The public schools of England, part 2" North American Review 129: 37-52

Isaacs, D (2010) "Realising the right to education in South Africa: Lessons from the United States of America" SAJHR 26: 356-385

Jones, FH (2008) Tirocinium Imperii: Public School Education in the Victorian Era, the Classical Curriculum, and the British Imperial Ethos (BAHons dissertation, Wesleyan University)

Kahn, E (1951) "Equality of the official languages: The Transvaal Education Ordinance case" SALJ 68: 353-359

Kahn, E (1960) “The late right Hon NJ de Wet” SALJ 77: 133-134

Kahn, E (1980) “Oliver Deneys Schreiner - The man and his judicial world” SALJ 97: 566-615

Kahn, E (1999) Law, Life and Laughter Encore: Legal Anecdotes and Portraits (Cape Town)

Kahn, E (2005) "Further reflections of Mr Justice McGregor on Lord de Villiers" SALJ 122: 263-268

Kenway, J et al (2017) Class Choreographies: Elite Schools and Globalization (London)

Khandlhela, RS (1993) Marianhill Mission and African Education, 1882-1915 (MA dissertation, University of Natal)

Kilner, D (1804) First Going to School, or the Story of Tom Brown and His Sisters (London)

Kipling, R (1899) Stalky \& Co (London)

Knowles, J (1959) A Separate Peace (New York)

Landis, ES (1962) "South African apartheid legislation II: Extension, enforcement and perpetuation" Yale LJ 71: 437-500

Lawson, KC (1968) Venture of Faith: The Story of St John's College, Johannesburg (Johannesburg)

Leonie, A (1965) The Development of Bantu Education in South Africa: 1652-1954 (PhD thesis, Montana State College)

Le Roux, CS (1998) A Historical-Educational Appraisal of Parental Responsibilities and Rights in Formal Education in South Africa, 1652-1910 (DEd thesis, University of South Africa)

Le Roux, CS (2016) "Schooling in the early Orange Free State: Inception to Union, 1836-1910" New Contree 76: 125-147

Le Roux, NJ (2002) "Die Hoër Jongenskool, Wellington” in E Smit et al Die Geskiedenis van Wellington en Distrik tot 2000 (Wellington)

Levi, L (ed) (1865) “Colleges and Schools” Annals of British Legislation 14: 297-394

Linnegar, J (1979) SACS - 150 Years: A History of the South African College Schools (Cape Town)

Loram, CT (1917) The Education of the South African Native (London)

Loveland, I (1999) By Due Process of Law? Racial Discrimination and the Right to Vote in South Africa 1855-1960 (Oxford and Portland, Oregon) 
Lugtenburg, AH (1925) Geskiedenis van die Onderwys in die SA Republiek (1836-1900) (Pretoria)

Lyon Clark, B (2001) Regendering the School Story: Sassy Sissies and Tattling Tomboys (New York)

MacKenzie, JM (2007) The Scots in South Africa: Ethnicity, Identity, Gender \& Race, 1772-1914 (Manchester)

Macquarrie, JW (1956) “The new order in Bantu education” Africa South 1: 32-42

Mahuma, SM (2004) The Development of a Culture of Learning Among the Black People of South Africa, 1652-1998 (MEd dissertation, University of South Africa)

Malan, AN (1888) Ernest Fairfield, or Two Terms at St Andrew's (London)

Malan, AN (1898) Schooldays at Highfield House (London)

Malan, DD (1948) “Die tydperk van Mnr FP Roux, 1903-1928” in Wellington BHS Jubilee Issue, 1868-1948 (Cape Town)

Malan, JR (1922) The Re-organisation of Rural Education in the Cape Province of the Union of South Africa (PhD thesis, Columbia University)

Malan, R (2008) Cheesecutters and Gymslips: South Africans at Boarding School (Roggebaai)

Malherbe, EG (1925) Education in South Africa vol I: 1652-1922 (Cape Town)

Malherbe, EG (1939) “The South African educational system” in Bulletin of Educational Statistics for the Union of South Africa (Pretoria)

Malim, FB (1948) Almae Matres: Recollections of Some Schools at Home and Abroad (Cambridge)

Mangan, JA (2000) Athleticism in the Victorian and Edwardian Public School(Abingdon)

Manson, E \& WR Bisschop (1905) "Review of legislation, 1903: South Africa" J of the Society of Comparative Legislation 6(2): 391-417

Marais, JS (1957) The Cape Coloured People, 1652-1937 (Johannesburg)

Marais, JS (1961) The Fall of Kruger's Republic (Oxford)

Marples, M (1940) Public School Slang (London)

Mashale, FK (2009) The Provision of Education at Medingen Mission Station since 1881 (MEd dissertation, University of South Africa)

Mathabatha, NIS (2005) The Struggle over Education in the Northern Transvaal: The Case of Catholic Mission Schools, 1948 to 1994 (Amsterdam)

McConnell, J (1985) English Public Schools (London)

McCulloch, G (1991) Philosophers and Kings: Education for Leadership in Modern England (Cambridge)

McGregor, AJ (1922) “The late Chief Justice: Baron de Villiers” SALJ 39: 52-58

McGregor, AM (1977) Blythswood Missionary Institution, 1877-1977: “Ora et Labora”, the Story of the Great Scottish-Fingo Institution in the Transkei (King William's Town)

McIntyre, D (1950) The Diocesan College: A Century of "Bishops" (Cape Town)

McWhinney, E (1954) "Race relations and the courts in the Union of South Africa" The Canadian Bar Review 32: 44-74

Mentz, JF (1941) Kwartmillennium-gedenkboek van die NG Gemeente, Paarl (Paarl) 


\section{DM PRETORIUS}

Metrowich, FC (1929) The Development of Higher Education in South Africa, 1873-1927 (Cape Town)

Mokwele, PPA (1988) The Grace Dieu Experience of the Anglican Church, 1906-1958 (MEd dissertation, University of the North)

Molteno, F (1988) "The historical foundations of the schooling of black South Africans" in P Kellaway (ed) Apartheid and Education: The Education of Black South Africans (Johannesburg): 45-107

Moore, AJ (1990) Natal's Native Education (1917-1953): Education for Segregation (MA dissertation, University of Natal)

Mount, H (2013) "Public-school slang continues to thrive" The Spectator 7 September 2013

Mphahlele, E (1959) Down Second Avenue (Johannesburg)

Musgrave, PW (1985) From Brown to Bunter: The Life and Death of the School Story (London)

Ntantala, P (1960) "The abyss of Bantu education" Africa South 4: 42-47

O'Connor, H (1974) No Other School So Dear: A History of the Eunice Schools, 1875-1970 (Bloemfontein)

Odendaal, A (2003) The Story of an African Game: Black Cricketers and the Unmasking of One of Cricket's Greatest Myths (Cape Town)

O’Neill, C (2014) Catholics of Consequence: Transnational Education, Social Mobility and the Irish Catholic Elite 1850-1900 (Oxford)

Paola, LJ (ed) (1967) Marist Centenary Digest (Johannesburg)

Pascoe, CF (1901) Two Hundred Years of the SPG: An Historical Account of the Society for the Propagation of the Gospel in Foreign Parts, 1701-00 vol 2 (London)

Peacock, MA (1972) Some Famous Schools in South Africa, Vol 1: English Medium Boys' Schools (Cape Town)

Pierson, AT (1894) The Huguenot College and Seminaries, South Africa (Meriden, Connecticut)

Ploeger, J (1952) "Onderwys en onderwysbeleid in die Suid-Afrikaanse Republiek" in C Beyers (ed) Archives Year Book for South African History 15: 1-365

Poland, M (2008) The Boy in You: A Biography of St Andrew's College, 1855-2005 (Simonstown)

Pretorius, DM (2004) The Functus Officio Doctrine in South African Administrative Law, with Reference to Analogous Principles in the Administrative Law of Other Commonwealth Jurisdictions ( $\mathrm{PhD}$ thesis, University of the Witwatersrand)

Pretorius, DM (2019) "Bricks in the wall or the spice of 'good life'? Independent schools in South African law" South African LJ 136: 605-649

Quigly, I (1982) The Heirs of Tom Brown (London)

Randall, P (1982) Little England on the Veld: The English Private School System in South Africa (Johannesburg)

Reed, JR (1964) Old School Ties: The Public Schools in British Literature (Syracuse)

Reed, JR (1974) “The public schools in Victorian literature” Nineteenth-Century Fiction 29: $58-76$

Richards, F (1947) Billy Bunter of Greyfriars School (London)

Richards, J (1988) Happiest Days: The Public Schools in English Fiction (Manchester) 


\section{PRIVATE SCHOOLS IN SOUTH AFRICAN LEGAL HISTORY}

Rodger, A (1977) The Early History of Blythswood Missionary Institution (BD dissertation, Rhodes University)

Rose Innes, Sir James (1914) “Obituary: The late Chief Justice” SALJ 31: 422-424

Rowling, JK (1997) Harry Potter and the Philosopher's Stone (London)

Ruskin, S (2004) John Herschel's Cape Voyage: Private Science, Public Imagination (Aldershot)

Russell, Lord John (1823) An Essay on the History of the English Government and Constitution from the Reign of Henry VII to the Present Time (London)

Sales, J (1975) Mission Stations and Coloured Communities of the Eastern Cape, 1800-1852 (Cape Town)

Saule, AMM (1985) Missionaries and the Xhosas - A Comparison of the Educational work of Christian Missionary Societies (MEd dissertation, University of the Witwatersrand)

Salinger, JD (1951) The Catcher in the Rye (New York)

Schoeman, K (2015) Imperiale Somer: Suid-Afrika tussen Oorlog en Unie, 1902-1910 (Pretoria)

Searle, F St L (1933) “The Hon Mr Justice James Buchanan” SALJ 50: 137-144

Seldon, A \& D Walsh (2013) Public Schools and the Great War: The Generation Lost (Barnsley)

Seroto, J (1999) A Historical Perspective of Formal Education for Black People in the Rural Areas of the Northern Province (MEd dissertation, University of South Africa)

Shepherd, RHW (1940) Lovedale, South Africa: The Story of a Century, 1841-1941 (Alice)

Shrosbree, C (1988) Public Schools and Private Education: The Clarendon Commission 1861-64 and the Public Schools Acts (Manchester)

Skota, TDM (1932) The African Yearly Register, Being an Illustrated National Biographical (Who's Who) of Black Folks in Africa (Johannesburg)

Smith, T (1963) Leon at Clan College (Cape Town)

Smurthwaite, AG (1981) The Private Education of English-Speaking Whites in South Africa (MEd dissertation, Rhodes University)

Spark, M (1961) The Prime of Miss Jean Brodie (London)

Squelch, JM (1997) Private Education in South Africa: The Legal Status and Management of Private Schools (DEd thesis, University of South Africa)

Stephen, M (2018) The English Public School: A Personal and Irreverent History (London)

Stewart, J (1894) Lovedale Missionary Institution, South Africa (Glasgow)

Sundkler, B \& C Steed (2004) A History of the Church in Africa (Cambridge)

Suzman, A (1960) "Race classification and definition in the legislation of the Union of South Africa" Acta Juridica 339-345

Swartz, R \& J Wassermann (2016) “'Britishness', colonial governance and education: St Helenian children in colonial Natal in the 1870s" J of Imperial and Commonwealth History 44: 881-899

Tartt, D (1992) The Secret History (New York)

Taylor, DJ (2019) “Gilded Youth by James Brooke-Smith review - Privilege, rebellion and the British public school" 6 April 2019 Guardian

Thackeray, WM (1848) Vanity Fair: A Novel Without a Hero (London)

Thackeray, WM (1854) The Newcomes: Memoirs of a Most Respectable Family (London) 


\section{DM PRETORIUS}

Thompson, LM (1954) "Constitutionalism in the South African Republics" Butterworths SALR: 49-72

Thomson, DH (1961) The Story of a School: A Short History of the Wynberg Boys' High School (Wynberg, Cape)

Tindall, BA (1943) “The Chief Justice” SALJ 60: 275-279

Turner, D (2015) The Old Boys: The Decline and Rise of the Public School (New Haven)

Van de Ruit, J (2005) Spud (Johannesburg)

Van Niekerk, JP (2013) “An introduction to South African law reports and reporters, 1828-1910" Fundamina 19(1): 106-145

Various Authors (1893) Great Public Schools (London)

Veitch, N (2016) Brothers in an Endless Chain: Celebrating 175 Years of the Wynberg Boys' Schools (Cape Town)

Venter, P (1950) Die Groei van Onderwysaangeleenthede in Johannesburg, 1886-1920 (PhD thesis, Potchefstroom University College)

Volz, S (2014) “The rise and fall of the Moffat Institution" SA Historical J 66: 470-485

Walker, EA (1929) The South African College and the University of Cape Town (Cape Town)

Waquet, F (2001) Latin or the Empire of a Sign (London)

Warner, R (1946) English Public Schools (London)

Waugh, E (1928) Decline and Fall (London)

Waugh, E (1982) Charles Ryder's Schooldays (London)

Webster, T (2013) Healdtown: Under the Eagle's Wings - The Legacy of an African Mission School (Cape Town)

Wessels, Sir John (1931) "Tribute to the first judges of Appellate Division" SALJ 48: 459-463

Wessels, Louis (1964) Die Nuwe Seun (Cape Town)

Whiteside, J (1906) History of the Wesleyan Methodist Church of South Africa (London)

Wilkinson, A (1992) The Community of the Resurrection: A Centenary History (London)

Willans, G (1953) Down with Skool (London)

Winter, AJE (1970) Till Darkness Fell (Mirfield)

Winterbach, H (1994) The Community of the Resurrection's Involvement in African Schooling on the Witwatersrand, from 1903 to 1956 (MEd dissertation, University of the Witwatersrand)

Wodehouse, PG (1903) Tales of St Austin's (London)

Wodehouse, PG (1909) Mike at Wrykyn (London)

Wodehouse, PG (1909) Enter Psmith (London)

Woeber, CA (2000) "A Good Education Sets Up a Divine Discontent”: The Contribution of St Peter's School to Black South African Autobiography (PhD thesis, University of the Witwatersrand)

Wolff, T (2003) Old School (New York)

Wood, AA (1972) "Shine Where You Are": A Centenary History of Inanda Seminary, 1869-1969 (Alice) 
PRIVATE SCHOOLS IN SOUTH AFRICAN LEGAL HISTORY

\section{Case law}

\section{South Africa}

Alice Municipality v Lovedale Missionary Institution 1938 EDL 160

Cape Provincial Administration v Xabanisa 1941 AD 203

Christian Brothers College v Kimberley Municipality 1935 GWLD 37

Christian Brothers v Kimberley Municipality 1936 AD 220

Colonial Secretary v Molteno School Board (1910) 20 CTR 159

Council of The Diocesan College v The Rondebosch Municipality (1901) 18 SC 112

De Aar Divisional Council v Convent of the Holy Cross 1952 (1) SA 495 (C)

De Bruin v Director of Education 1934 AD 252

De Gouveia v Superintendent-General of Education 1954 (3) SA 1009 (C)

Dominican Convent v South Shepstone Local Board (1923) 44 NLR 391

Macintosh v Pretoria School Board \& Sunnyside School Committee 1908 TS 872

Marist Brothers' Trustees v Port Elizabeth Municipality 1924 AD 487

Marist Brothers v Port Elizabeth Municipality 1948 (4) SA 698 (A)

MEC for the Eastern Cape Department of Education v Playways Pre-Primary School [2018] ZAECELLC 4

Moller v Keimoes School Committee 1911 CPD 673

Moller v Keimoes School Committee 1911 AD 585

Moller v Keimoes School Committee 1911 AD 635

Molteno School Board v Molteno Municipal Council 1912 AD 772

Seneque v Natal Provincial Administration 1940 AD 149

Springfield Public Schoolv Baumgarten (1906) 16 CTR 22

Superintendent-General of Education (Cape) v Fife 1955 (2) SA 279 (A)

Swart NO \& Nicol NO v De Kock; Swart NO \& Nicol NO v Garner 1951 (3) SA 589 (A)

Wellington Boys' High School Committee v Wellington School Board 1920 CPD 522

Wellington Municipality v Huguenot Seminary 1939 CPD 15

\section{United Kingdom}

Ackworth School v Betts (1915) 6 TC 642

Dilworth v Commissioner of Stamps [1899] AC 99

Hayman v Governors of Rugby School (1874) LR 18 Eq 28

The General Committee for Ackworth School v Betts (1915) 6 TC 642

The Girls' Public Day School Trust v Ereaut [1931] AC 12 


\section{DM PRETORIUS}

\section{United States}

Brown v Board of Education of Topeka 347 US 483 (1954)

Parents Involved in Community Schools v Seattle School District No 1511 US 701 (2007)

\section{Legislation}

\section{South Africa}

Bantu Education Act 47 of 1953

Blacks (Urban Areas) Consolidation Act 25 of 1945

Consolidated Education Ordinance 5 of 1921 (Cape)

Constitution of the Republic of South Africa, 1996

Education Act 13 of 1865 (Cape)

Education Act 4 of 1874 (Transvaal)

Education Act 10 of 1880 (Transvaal)

Education Act 1 of 1882 (Transvaal)

Education Act 25 of 1907 (Transvaal)

Education Ordinance 7 of 1903 (Transvaal)

Education Ordinance 20 of 1956 (Cape)

Private Schools Act (House of Assembly) 104 of 1986

Republic of South Africa Constitution Act 110 of 1983

School Board Act 35 of 1905 (Cape)

South African Schools Act 84 of 1996

\section{United Kingdom}

Public Schools Act, 1868 (31 \& 32 Vict c 118)

South Africa Act, 1909 (9 Edw VII c 9) 